\title{
Fetvâ ve Mezhep \\ Fetvâ Usûlü ve Tarihinin Tartışmalı Bir Konusu Olarak Fetvâ-Mezhep İlişkisi
}

\begin{abstract}
Prof. Dr. Ahmet YAMAN *
Öz: Fıkhî mezhepler, hukuk emniyetini sağlamak amacıyla sivil birer gerçeklik olarak oluşmuş ve yayılmıştır. Dinî-hukukî hayatı tanzim eden fetvâ da daha çok hukukî istikrar endişesiyle bu mezheplerden birisine bağlı bir faaliyet olarak süre gelmiştir. Bu gerçek, ehliyetli ve dirayetli bir müftîyi, bağlı olduğu mezhebi her zaman ve durumda mutlaka iltizam etmek ve onun çerçevesinin dışına asla çıkmamak zorunda bırakmaz. Nitekim fakihlerin çoğunluğu, amelî hayatın belli bir mezhebe göre sürdürülmesini caiz görmekle birlikte, bunun mutlaka yerine getirilmesi gereken bir dinî gereklilik olmadığı kanaatindedir. Fıkıh doktrinini usûlü, ilkeleri ve furûuyla kavrayabilen âlim bir müftî, metodolojik ve olgusal gerekliliklere bağlı olarak, kendi mezhebi içindeki görüşlerden birisini tercihle fetvâ verebileceği gibi, kendi mezhebi dışında bir başka görüşü benimseyip onunla da fetvâ verebilecektir. Aynı minvalde, metodolojik bir tavır ve ilkesel bir yaklaşım çerçevesinde fikıh mirasının bütününden faydalanmak mümkün olduğundan, bilinen dört mezhebin dışına da çıabilecektir.
\end{abstract}

Anahtar Kelimeler: Fetvâ, mezhep, telfîk, müftî.

Fatwa And Madhhab The Relation Between Fatwa and Madhhab as a Debated Subject of Fatwa Methodology and History

\begin{abstract}
Fiqh madhahib came into life and expanded as civic realities in order to secure legal certitude. Whereas fatwa, as the organization of religiou-legal life, has continued to be an activity relying on one these madhahib due to the concern of mostly legal stability. This fact does not force a capable and astute mufti to always and in all occasions to follow his own madhhab and never leave out its working framework. Thus, the majority of fuqaha, though see it permissible to live according to a certain madhhab, do not think that it is an absolutely necessary religious duty to do so. A scholarly mufti who can comprehend the fiqh doctrine with its methods, principles and issues, depending on methodological and factual necessities, can either issue a fatwa by choosing one of the opinions within his own madhhab or give a fatwa by adopting an opinion outside his madhhab. Similarly, since it is allowed to benefit from the total figh heritage within the framework of methodological action and on principal grounds, one can also step out of the known four madhahib.
\end{abstract}

Keywords: Fatwa, madhhab, compiling, mufti.

\section{Giriş}

Dinî sorulara cevap aramak gibi hem dünya hem de âhiret açısından son derece önemli olan bir işin kuralsız, yöntemsiz ve erdemsiz olarak yerine getirilmesi düşünülemez. Fetvâ verme (iftâ)

* NEÜ İlahiyat Fakültesi Öğretim Üyesi. 
işleminin belli ilkeler ve yöntemler doğrultusunda gerçekleştirilmesi, elden geldiğince isabetli hükme ulaşma ana hedefi yanında:

1. Toplumda hukuk emniyetini sağlamak,

2. Fetvâ standardizasyonunu sağlamak,

3. Dinî hükümlerin mükellef tarafından benimsenmesine katkıda bulunmak,

4. Buna bağlı olarak fikhın canlıllğını ve toplumsal yürürlüğünü sürdürmek,

5. Ehliyetsiz kişilerin istismarını engellemek,

6. Fıkhî ve mezhebî tutarlılığı temin etmek,

7. Küçük ölçekte mezhebin, büyük ölçekte fikhın devamlılığını sağlamak bakımlarından da son derece önemlidir.

Teorik olarak bir müslüman, karşılaştığı amelî sorunların çözümünü, eğer bilgisi ve hüküm çıarma ehliyeti varsa dinin ana kaynaklarında bizzat arayabilir. Buna güç yetiremez ya da aradığını bulamazsa bir bilene sorar, sorulan uzman kişi de nesnel bir yöntem ve standart ilkeler doğrultusunda Kitap ve Sünnet’ten çıkaracağı veya bu ikisinden onay alacağı bir çözümü bulmaya çalışır. İşte bu eylemler sırasında takip edilen yol ve kullanılan yöntem, doktrinde fetvâ usûlü kavramıyla ifade edilmiştir.

Mezhebe gelince, bilindiği üzere, hükümlerinin dayandığı delilleri bulmakta ve bunlardan hüküm çlkarıp yorumlamakta önder sayılan âlimlerin ortaya koyduğu görüşlerin tamamına ve bu görüşler etrafında meydana gelen ekolleşmenin ürünü olan ilmî ve fikrî birikime mezhep denmektedir.

II/VIII. yüzyılın ortalarından itibaren ders halkaları kurup fikhın bütün alanlarında hüküm üreten ve yetiştirdikleri öğrencileri eliyle kendi görüşlerini yazıp yayan müctehidler, daha sonra kendi adları veya nisbeleriyle anılacak olan mezheplerin kurucu imamları sayılacaklarıdır. İşbu mezheplerin ortaya çıkmasını ve yaygınlaşmasını kabaca şu sebeplerle açılamak mümkündür:

a. Önceleri gerektikçe ve soruldukça ictihad edilip hüküm verilirken bu dönemdeki müctehidler, fikhın bütün alanlarında çalışmalar yapmıştır.

b. Bu çalışmalar, her bir müctehidin etrafında kurulan ders halkalarında $(\mathrm{Mu}-$ hammed Hamîdullah’n (ö. 2002) deyimiyle "akademilerde") yapılmış, yetiştirilen öğrenciler vasıtasıyla mezhebin (ekolün ve akademinin) görüşleri etrafa yayılmıştır.

c. Müctehidin ve önde gelen öğrencilerinin görüşleri kitaplarda tedvin edilmiş, böylece bir bütün halinde kolayca takip ve öğrenme imkanı doğmuştur.

d. Her bir mezhebin hüküm kaynaklarına ve istinbat yöntemlerine dair kuralları yani takip ettikleri fikıh usûlü berraklaşmış ve yazıya geçirilmeye başlanmıştır. 
e. Mezhepler arasında karşılıklı tartışmalar olmuş ve her ekol kendi görüşünün doğruluğunu ispat etmeye çalışmıştır.

f. Müctehid imamların öğrencilerle ve kitaplarla etrafa yayılan şöhretleri, büyük kitlelerin onları takip etmesini sağlamıştır.

g. Tayin edilen kadılar, kendi mezheplerine göre karar vermeye başlamış, hatta kadı atamalarında mezhep faktörü de dikkate alınır olmuştur.

h. Hukuk güvenliğini sağlama, yani kişilerin kendilerine uygulanacak hükümleri önceden bilmelerini sağlayarak ve bir bölgede aynı mahiyetteki olaylara aynı hükmü vererek hukuk birliğini, istikrarını ve adaleti gerçekleştirme ihtiyacı, geniş halk kitlelerini belli bir müctehid imamı esas alıp onun mezhebini kanun gibi görmeye sevk etmiştir.

1. Bir müddet sonra fıkhın bütün konularına ilişkin mezhep görüşlerini sistematik bir tarzda sıralayan temel metinler yazılmaya ve mezhep büyüklerinin kitaplarının şerh edilmeye başlanması, hem ekol kimliğini perçinlemiş hem de hukuk güvenliğini sağlayan araçlar olarak görülmüştür.

j. Yeni meselelerin mezhep imamı ve yetişkin öğrencilerinin mevcut görüşlerine ve takip ettikleri usûle göre çözümlenmesine (tahrîc) ilişkin kurallar tespit edilerek, serbest ictihaddan çok, iç tutarlılık kaygısına bağlı mezhep içi ictihadlar yapılmaya başlamıştır.

k. Bazı sosyal, siyasal ve kültürel etkenlerin sınırlı da olsa ekoller arasında bir tür rekabet doğurması, mezhepler ile müntesiplerinin daha belirgin hatlarla ayrışmasına sebep olmuştur.

Başlıca bu sebeplere bağlı olarak ortaya çıkan fıkıh mezhepleri, gittikçe kökleşmiş ve bilinen dört tanesi başta olmak üzere İslâm coğrafyasında istikrar kazanmıştır. Mezheplerin istikrar kazanmasındaki en önemli sebebin, yukarıda da kısmen değinildiği gibi, hukuk güvenliğinin ve birliğinin sağlanması ihtiyacı olduğu söylenir.

Esasen bu ihtiyaç çok önceleri hissedilmiş ve bunu karşılamak üzere resmî düzeyde adımlar da atılmıştı. Emevîler döneminde halife Ömer b. Abdilazîz’e (ö. 101/720) yargı birliğini sağlaması yönünde teklifler yapılmış, o da görüş ayrılıklarını "rahmet" olarak değerlendirmekle birlikte ${ }^{1}$ eyaletlere genelgeler göndererek her eyaletin kendi bölgesindeki fakihlerin ittifak ettikleri hükümlere göre karar vermelerini emretmiști. ${ }^{2}$ Daha sonra Abbasîler döneminde halife Ebû Ca'fer el-Mansûr da (ö. 158/775) benzer bir girişimde bulunmuştu. Danışmanlarından Abdullah b. elMukaffầnın (ö. 142/759), birbirine zit görüşler hukuk anarşisine yol açtığı için devlet eliyle resmî bir kanun derlemesi yapılması yönündeki teklifini yerinde bulan halife el-Mansur, İmam Mâlik'in (ö. 179/795) el-Muvatta'ını kanunlaştırmak istemiş fakat İmam Mâlik, bilgi-rivayet zenginliğinden istifadeyi ve fikhın gelişmesini engelleyeceği endişesiyle buna onay vermemiştir. ${ }^{3}$

1 Şâtıbî, el-Muvâfakât, Beyrut 1991, IV /94.

2 Dârimî, “Mukaddime”, 52; Koca, Ferhat, "Mezhep: Fıkıh”, DİA, XXIX, 538. Ömer b. Abdilaziz’in kendi emriyle yapılan sünnet, hadis ve eser derlemelerini istifade edilmek üzere etrafa göndermesi konusunda bk. İbn Abdilber, Câmiu beyâni'l-ilm ve fadlih, Kahire 1982, s. 127; Kâdî İyâz, Tertîbü'l-medârik ve takrîbü'l-mesâlik li ma'rifeti a’lâmi mezhebi Mâlik, (thk. Muhammed T. Tancî ve dğr.), Mağrib 1983, I, 39.

3 Hacvî, el-Fikru's-sâmî fî târîhi'l-fikhi'l-İslâmî, Beyrut 1995, I-II, 406-407; Ebû Zehra, Mâlik, Kahire 1978 (?), s. 180 - 
Bütün bunlara rağmen yukarıda başlıcalarını saydı̆̆ımız sebeplere bağlı olarak fıkhî mezhepler, sivil birer gerçeklik olarak oluşmuş ve yayılmıştır. Dinî-hukukî hayatı tanzim eden fetvâ da daha çok hukukî istikrar endişesiyle bu mezheplerden birisine bağlı bir faaliyet olarak süre gelmiştir. Burada fetvâ usulünün işte bu önemli ve yer yer tartışmalı meselesini yani fetvânın belli bir mezhebin çerçevesini aşıp aşamayacağı konusunu ve fetvâ-mezhep ilişkisiyle bağlantılı bazı ayrıntıları değişik açılardan ele almaya çalışacağız.

\section{Bir Mezhebe Bağlanmanın Gerekliliği Meselesi ve Mezhep Dışına Çıkmayı Gerektiren Sebepler}

Fakihlerin çoğunluğu amelî hayatın belli bir mezhebe göre sürdürülmesini caiz görmekle birlikte, bunun mutlaka yerine getirilmesi gereken dinî bir gereklilik olmadığ kanaatindedir. ${ }^{4}$ Hicrî II. yüzyılın sonlarından itibaren hissedilir biçimde belirginleşmeye başlayan fikhî-amelî mezhepler esasen, toplumdaki hukuk emniyetini ve istikrarını sağlama ihtiyacını karşılayan araçlar konumundadır. Bireyler kendi ibadet-hukuk hayatlarını belli bir disiplin ve tutarlılık içinde yürütmek; kamusal irade sahipleri de hukuk birliğini sağlayarak adalet duygusunda olabildiğince müşterek bir hukuk toplumu oluşturabilmek için belli bir fikıh mezhebini takip etmeyi uygun bulmuştur. Şeyhülislam Ebussuûd Efendi’nin (ö. 982/1577) sorulara fetvâ verirken kullandığı ifadeler, mezkûr durumun somut bir örneğidir:

"Mes'ele: "Zevci nâbedîd (mefkûd, kayıp) olan Hind, nafakaya aczi olacak teşeffu' edip (Şâfiî mezhebini benimseyip), Şâfî̀ kadısı tefrik edip zevc-i âhara varsa, ba'dehû Zeyd gelse zevcesin geri alabilir mi?

el-Cevab: Teşeffu' (şâfiî̀ mezhebiyle amel) hususu Diyâr-ı Rûmıda cârî olmaya deyu men-i sultanî vâki olmuştur."

"Mes’ele: "Yemin eden Zeyd, Şâfiî kâdîsine müracaat edip, yemin hal eylese sahih olur mu?

el-Cevab: Teşeffu' hususu Diyâr-ı Rûm'da câri olmaya deyu men-i sultanî vâki olmuştur."

“Mes'ele: Hükm ale’l-ğâib nâfiz olur mu?

el-Cevab: Hâkim Şâfiî olmayub, mahkûm aleyh Şâfiî olmayıcak olmaz."7

181; Kandemir, M. Yaşar, "Muvatta”, DİA, XXXI, 416; Koca, "Koca, "Mezhep: Flkıh”, DİA, XXIX, 538.

4 bk. Mâverdî, Edebü’l-kâdî, (thk. M. H. Serhân), Bağdat 1972, I, 185-186, 269 vd.; Nevevî, el-Mecmû şerhu'l-Mühezzeb (nşr. M. N. el-Mutîi), Cidde ts. (Mektebetü'l-İsşâd), I, 92-93; Süyûtî, İhtilâfu'l-mezâhib (nşr. A. Bestevî), Kahire 1989, s. 41 vd.; İbn Nüceym, el-Bahru'r-râik şerhu Kenzi'd-dekâik, Kahire 1311, VI, 289-290; İbnü'l-Kayyım, I'lâmu'lmuvakkî̀n an Rabbi'l-âlemîn, Beyrut 1991, IV, 165, 181-188; Emîr Padişah, Teysîru't-Tahrîr, Kahire 1351, III, 228-231, 253-254; Dehlevî, Şah Veliyyullah, Ikdü'l-cîd fî ahkâmi'l-ictihâd ve't-taklîd, Kahire 1978, s. 3 vd.; Şevkânî, İrşâdü’lfuhûl (thk. E. el-Eserî), Riyad 2000, s. 1105 vd.; Mehmed Seyyid Bey, Usûl-i Fikıh: Medhal, İstanbul 1333, I, 297-298; İzmirli, İsmail Hakkı, İlm-i Hilâf, Dersaadet 1330, s. 272; Karaman, Hayreddin, İslâm Hukukunda İctihad, Ankara 1985, s. 157-162, 217-220 ; Telkenaroğlu, M. Rahmi, Tevcîhü'l-halef fìmâ’htelefe fîhi’s-selef, İzmir 2013, s. 105-109, 153159; Koca, "Mezhep:Fikıh", DİA, XXIX, 541.

5 Düzdağ, Ertuğrul, Şeyhülislam Ebussuûd Efendi Fetvâları Işı̆̆ında 16. Asır Türk Hayatı, İstanbul 1983, s. 44. Verilen tefrîk kararının gerekçesi, Zeyd'in mefkûd olması değil, nafakayı temin etmemesidir.

6 Düzdağ, age., s. 138.

7 Düzenli, Pehlül, Șeyhulislâm Ebussuûd Efendi ve Fetvâları, İstanbul 2012, s. 370. Şu cümleler de onundur: "Kudât-1 
Her ne kadar "Sıradan kişinin (âmmî) mezhebi olmaz. Onun mezhebi, danıştı̆̆ı müftînin mezhebidir" "kuralı varsa da bu kural, sıradan kişinin bilgi, araştırma, mukayese ve tahlile dayalı bilinçli bir mezhep tercihinin olmadığı; bunun yerine mezhebini, yaşadığı toplumda bulunan müftîler ile orada hâkim olan hukuk anlayışının belirlediği anlamındadır. İster müctehid olsun ister bir müctehide tâbi olsun, müftîler de belli bir mezhep usûlünü ve çerçevesini takip edegeldiklerinden fetvâ da öyle veya böyle belli bir mezhep sistematiğini takip etmekten bütünüyle bağımsız kalamaz. Hal böyle olunca fetvâda kendiliğinden bir mezhebe bağlllık durumu zuhur eder.

Bu gerçek, ehliyetli ve dirayetli bir müftîyi, bağlı olduğu mezhebi her zaman ve durumda mutlaka iltizam etmek ve onun çerçevesinin dışına asla çıkmamak zorunda bırakmaz. ${ }^{9}$ Hanefî âlim Ebû Zeyd ed-Debûsînin (ö. 430/1039) şu yorumu bu bağlamda gerçekten câlib-i dikkattir:

"İnsanlar ilk dönemlerde yani sahâbe ve tâbiûn dönemlerinde delile göre hareket ediyor; sırasıyla Kurân'dan, Sünnet’ten ve sahabenin görüşlerinden delil olmaya elverişli şeyleri alıyorlardı. Kişi bir meselede Ömer'in ictihadıyla amel ederken bir başka meselede bu defa Ali’nin görüşüyle amel ediyordu. Ebû Hanîfe'nin önünde yetişen ashabı da bir defasında ona uyarken, başka bir defasında apaçı gördükleri bir delile istinaden ona muhalefet ediyordu. Şeriatta Ömer'e veya Ali'ye mensup olmak diye bir durum söz konusu değildir. Aksine, mensubiyet Allah’ın Resûlü’nedir. Hz. Peygamber'in (s.a.) övdüğü çağlarda (sahabe ve tâbiûn dönemlerinde) yaşayanlar delili/doğruyu, âlimlerine veya kendilerine ait zannetmiyorlardı. Ne var ki, dördüncü yüzyılda yaşayanların çoğunda takva kaybolup insanlar delil arama konusunda tembelleşince âlimlerini hüccet yerine koydular ve onları taklit ettiler. Artık kimi Hanefî oldu, kimi Mâlikî, kimi de Şâfiî. Delili kişilerle kuvvetlendirip, doğrunun da bir mezhepte olduğuna inanmaya başladılar. Sonraki her nesil, kendi âlimleri ne demişse araştırma yapmaksızın onu taklit etti. Öyle ki, sünnetlerin yerini bid’atler aldı. Doğru, hevâ arasında kayboldu. Bu arada bir de kendilerine olan tutkularından dolayı Allah’ın sevgili kulları olduklarını söyleyen gruplar ortaya çıktı. Bunlar Allah'ın kendi kalplerinde tecelli ettiğini ve onlarla konuştuğunu iddia ettiler. Bundan dolayı kendi nefislerinin kuruntularını delil, hevâlarını ilah edindiler. Öyle ki, artık bunları gerçek delile ulaştıracak bir yol kalmadı. Allah bizi bütün bunlardan muhafaza buyursun".10

memâlik-i mahmiyye, müddeâ aleyh mezhebine muhalif hükümden memnûdurlar. İmzâ ve tenfîz dahi lağvdir”; "Kudât-1 asır kendi mezhepleri ashâbının akvâl-i zaîfeleri ile amele me’zûn değildir, fe keyfe sâir mezâhib aslı ile amele ikdâm eyleyeler”. Düzenli, age., s. 370-371.

8 Âmidî, el-İhkâm fî usûli'l-ahkâm, Beyrut ts. (Dâru'l-Kütübi'l-İlmiyye), IV, 450-454; İbnü's-Salâh, Edebü'l-müftî ve’lmüsteftî̀ (nşr. A. E. Kal'acî), Beyrut 1986, s. 87; İbn Hamdân, Sifatü'l-fetvâ ve'l-müftî ve'l-müsteftî (nşr. M.N. Elbânî), Dımaşk 1380, s. 71; Zerkeşî, el-Bahru'l-muhît, yy., ts. (Kahire 1992?), VI, 311; İbn Nüceym, el-Bahru'r-râik, II, 90, 316; Seyyid Bey, age., I, 298 ; İzmirli, age., s. 272; bk. Kâsımî, M. Cemaleddin, el-Fetvâ fi'l-İslâm, (thk. M.A. el-Kâdî), Beyrut 1986, s. 104-105, 169; Telkenaroğlu, Tevcîhül-halef, s. 198-200. krş. Nevevî, Âdabü'l-fetvâ ve'l-müftî ve'l-müsteftî (nşr. B. A. el-Câbî), Dımaşk 1988, s. 74-77.

9 Tartışmalar için bk. Âmidî, el-İhkâm, IV, 457; İbnü's-Salâh, age., s. 59-60; İbn Hamdân, age., s. 19-21, 39, 71; İbnü’lKayyım, age., II, 174-176; IV, 135, 181-192; Zerkeşî, age., VI, 320-325; Süyûtî, İhtilâfu'l-mezâhib, s. 43; Hâdimî, Mecâmiu'l-hakâik, İstanbul 1308, s. 43; Kâsımî, age., s. 155-158; Karaman, age., s. 203; Karadâvî, Yûsuf, İslâm Hukuku Evrensellik Süreklilik, (çev. A.Yaman-Y.Işıcık), İstanbul 1997, s. 140; Dahîl, Abdurrahman b. Muhammed, el-Fetvâ ehemmiyyetühâ davâbıtuhâ âsâruhâ, Medîne 2007, s. 303; Telkenaroğlu, age., s. 154-156; Atar, Fahrettin, "Fetvâ", DİA, XII, 491, 492.

10 Debûsî, Takvîmü'l-edille fî usûli’l-fikh, (thk. H.M. Meys), Beyrut 2001, s. 399. 
Asırlar sonra bir başka Hanefî âlim Kemâleddin İbnü’l-Hümâm (ö. 861/1457) “Bir kimse, Ebû Hanîfe ve Şâfiî gibi belli bir imamın mezhebine bağlanmış olsa, sonrasında mutlaka o mezhepte kalması şartı yoktur" diyecek ${ }^{11}$; nihayet İbn Âbidîn (ö.1252/1836) "Bir insana belli bir mezhebi iltizam etmek mecburiyeti yoktur. Kişi, kendi mezhebine muhalif olan başka bir imamın görüşüyle şartlarını tamamlayarak amel edebilir"12 yorumunda bulunacaktır. Mütekellim usûlcülerden Seyfeddin el-Âmidî de (ö. 631/1233) kişinin her bir meseleyi farklı bir müftîye arz edebileceği görüşünü, sahabe icmasını ve selefin yaklaşımını gerekçe göstererek daha isabetli bulmuştur. ${ }^{13}$

Öyleyse mezheplerin hüküm ve delillerini, bunların usûl ve ilkelerini öğrenip kavrayabilen âlim bir müftî, bazı durumlarda kendi mezhebi dışında bir başka görüşü benimseyip onunla fetvâ verebilecektir. Dirayetli müftîye böyle bir değerlendirme yapma imkânı tanıyan durumlar, kanaatimizce şu şekilde sıralanabilir:

\section{A. Kendi mezhebinin delilinin olmadığı veya çok zayıf olduğu meselelerde.}

Bağlı olduğu mezhep içinde istikrar bulmuş olsa bile, delil ve dayanakları açısından tatmin edici olmayan görüşler, müftîye yeni bir değerlendirme firsatı sunabilir. Araştırmasının sonucunda söz konusu görüşün değil de diğer mezhebin görüşünün daha müdellel olduğuna kanaat getirirse o mezhep doğrultusunda fetvâ verebilir. Mesela kızı, annesi, kayınvâlidesi, halası gibi evlenmesi ebediyyen haram olan bir yakınına dokunma sonucu cinsel arzusu uyanan kişinin var olan nikâhının sona ereceği (hurmetü’l-müsâhera) görüşü, sağlam bir delile dayanmadığından, bu görüşü benimseyen bir mezhebe (Hanefîliğe) bağlı olan müftî, kendisini bununla kayıtlı görmeyebilecektir.

Önemli bir nokta olduğu için burada birkaç örnek daha vermek yerinde olacaktır:

İmam Gazzâlî (ö. 505/1111) sular konusunda, kendi İmamı Şâfiî̀nin (ö. 204/819) görüşü hakkında, "Onun bu konudaki kanaatinin Mâlik'in kanaati gibi olmasını ne kadar isterdim” demiş ve ardından İmam Mâlik'in “Su, ancak bozulmakla ve değişmekle necis olur” ictihadını tercih ettiren yedi ayrı delil sıralamıştır.

Mâlikî âlim Ebû Bekir İbnü’l-Arabî (ö. 543/1147), toprak ürünlerinin zekâtı meselesinde çerçeveyi dar ve geniş tutan mezheplerin görüşlerini naklettikten sonra, kendi mezhebinin görüşüne muhalefet edip, haklılığını ve sağlamlığını öne sürerek Ebû Hanîfe’nin (ö. 150/767) görüşünü benimsemiştir. Bu tercihinin gerekçelerini gösteren şu cümleleri, aynı zamanda müftînin hatt-1 harekâtının nasıl olması gerektiği yönündeki ilkeyi de öğretmektedir: "Bu meselede delil açısından en kuvvetli görüş, Ebû Hanîfe’nin görüşüdür. Fakirlerin lehine daha ihtiyatl olan ve nimetin şükrünü ifade bakımından daha uygun olanı yine budur. Zaten âyet ve hadislerin genel anlamları da buna işaret etmektedir." 14

\section{B. Mezhebinin deliline muhalif daha kuvvetli bir delil bulduğunda.}

İmam Şâfiî̀nin şu sözleri, benzer cümlelerle diğer imamlardan da nakledilmiştir: “Benim şu

11 Emîr Padişah, Teysîru't-Tahrîr, IV, 253.

12 İbn Âbidîn, Reddü'l-muhtâr, Beyrut ts. (Dâru İhyâi't-Türâsi'l-Arabî), I, 51.

13 Âmidî, el-İhkâm, IV, 458-459.

14 İbnü'l-Arabî, Ahkâmu'l-Kur'ân, II, 479 ve Âridatü'l-ahvezî Şerhu't-Tirmizî, III, 135'ten naklen Karadâvî, İslâm Hukuku, s. 108-109. 
kitabımda Allah Resûlünün sünnetine muhalif bir hüküm bulursanız, onun dediğini alın benimkini terk edin", "Bir hadis sahih ise benim görüşüm o hadis doğrultusundadır". ${ }^{15}$ Şu halde deliller arasında değerlendirme yapmaya muktedir, hadislerin sahihini böyle olmayanlarından ayırabilen bir müftî, bu hakka sahip olacaktır. Nitekim Nevevînin (ö. 676/1277) Şîrâzîye (ö. 476/1083) atfen verdiği bilgiye göre Şâfiîlerden Büveytî (ö. 231/846), Ebu’l-Kâsım ed-Dârekî (ö. 375/985), Ebu'lHasen İlkiyâ et-Taberî (ö. 504/1110) ve Beyhakî (ö. 458/1066) bu yöntemi uygulamış ve sahih gördükleri hadisler karşısında mezhebin hükmünü terk etmişlerdir. ${ }^{16}$

Muhtasar müellifi Kudûrî (ö. 428/1037), Hidâye şârihi Ebû’l-Fadl İbnü’ş-Şıhne (ö. 890/1485), Eşbâh şârihi Allâme Bîrî (ö. 1099/ 1688), birçok esere hâşiye yazdığ1 için "muhaşşî" diye anılan Sindî Tettevî (ö. 1138/1726) ve İbn Âbidîn (ö. 1252/1836) gibi bazı Hanefî âlimleri de benzer düşünceyi seslendirmişlerdir. ${ }^{17}$

Hanefî mezhebinin kurucu imamlarından Ebû Yûsuf'un (ö. 182/798) şu tercihleri, bir anlamda bu yaklaşımın örnekleri konumundadır: Ebû Hanîfe, toprak ürünlerinin zekâta tâbi olması için İbrahim en-Nehaîden gelen bir rivayete dayanarak nisap aramazken, Ebû Yûsuf “Beş veskten az mahsulde zekât yoktur"18 hadisini delil gösterip söz konusu hacim ölçüsüne ulaşmayan toprak ürünlerinde zekât sorumluluğu olmadığını söylemiştir. ${ }^{19}$ Aynı şekilde Ebû Hanîfe, Hz. Ali ve Nehaî̀den gelen bilgilere dayanarak sâime olan atlardan birer dinar zekât alınacağını ileri sürmüşken Ebû Yûsuf "Sizi/Ümmetimi at ve köle zekâtından muaf tuttum"20 hadisini esas alıp atların zekâta tâbi olmadığını söylemiştir. ${ }^{21}$

\section{Mezhepteki hükmün belirli bir tarihselliğe veya siyasete bağlı olarak konulduğu meselelerde.}

İçinde bulunulan tarihî-siyasî şartlar ya da toplumsallık, aynı zamanda o tarih ve toplumun bir ürünü olan fakihi bir duruş sergilemeye itebilir. Bu aslında her düzeydeki karar verici için geçerli bir durumdur. Dolayısıyla mezhep içinde tespit edilen ve zamanla yerleşen hüküm, belirli bir tarihselliğe ya da siyasete bağlı olabilir. Mezhep hükmünün böyle bir özellik taşıdığı anlaşılırsa, olgunun farklılaşmasına muvazi olarak o hükmün, işlevselliğini kaybedeceği söylenebilir. İște böyle durumlarda ilgili hüküm, yerini başka çözümlere bırakabilecektir. Mesela ücretli atanmış bir imamı (el-imam er-râtib) olsun olmasın, mescidlerde ilk cemaatın dışında, namaz için ikinci bir cemaat teşkil edilemeyeceği ictihadı ${ }^{22}$, siyasî içerikler taşıyan sapık, bid’atçi fırkalara camide buluşma ve toplum nezdinde taban kazanma fırsatı vermemek gibi tarihsel bir arka plana sahip olduğundan böyle endişelerin olmadığı yer ve zamanlarda benimsenmeyebilecektir.

Mevâlî olarak isimlendirilen gayrı Arap unsurlarla ilgili bazı fıkhî hükümler de aynı ka-

15 İbnü’s-Salâh, Edebü'l-müftî, s. 53-54; İbn Hamdân, Sifatü'l-fetvâ, s. 37; Nevevî, el-Mecmû, I, 104-105; İbnü'l-Kayyım, I’lâmu'l-muvakkıîn, IV, 179; Kâsımî, el-Fetvâ, s. 111-113. Ebû Hanîfe'nin sözü ve yaklaşımı olarak bk. İbn Abdilber, elİntikâ fî fedâili'-selâseti'l-eimmeti'l-fukahâ, Beyrut ts. (Dâru'l-Kütübi'l-İlmiyye), s. 144, 145; Zehebî, Menâkıbü'l-İmâm Ebî Hanîfe ve sâhıbeyh, Haydarâbâd ts. (Lecnetü İhyâi'l-Maârifi'n-Nu'mâniyye), s. 30; İbn Âbidîn, Reddü'l-muhtâr, I, 46; a.mlf., "Şerhu'l-Manzûmeti'l-müsemmât bi Ukûdi Resmi'l-müftî”, Mecmûatü'r-Resâil, İstanbul 1320, I, $24,27$.

16 Nevevî, el-Mecmî, I, 104-105; ayrıca bk. İbnü’s-Salâh, age., s. 53.

17 Şevkânî, İrşâdü'l-fuhûl, s. 1107; İbn Âbidîn, Reddü'l-muhtâr, I, 46; Kâsımî, age., s. 112-113.

18 Buhârî, "Zekât”, 4; Müslim, "Zekât”, 1; Ebû Dâvûd, "Zekât”, 2; Muvatta, "Zekât”, 1.

19 Ebû Yûsuf, Kitâbü’l-Harâc, Kahire 1382, s. 53.

20 Ebû Dâvûd, “Zekât”, 10; İbn Mâce, “Zekât”, 4, 15; Nesâî, “Zekât”, 16.

21 Ebû Yûsuf, age., s.77. Ebû Yûsuf'un benzer tercihlerinin ayrıntıları için bk. Özşenel, Mehmet, Ebû Yûsuf'un Hadis Anlayışı, İstanbul 2011, s. 143-151.

22 İbn Abdilber, el- İstizkâr, Kahire 1993, IV, 64-65, 68. 
tegoride değerlendirilebilir. Söz gelimi, onların idareye dönük taleplerini, siyasal ve toplumsal etkinliklerini kırmak amacıyla uydurulan "Araplar kendi aralarında birbirinin dengi, mevâlî de kendi aralarında birbirinin dengidir"23 ile "Araplar, acemlerin efendileridir"24 rivayetlerine dayanan hükümler böyledir. Mesela devlet başkanlığına hak sahibi olabilmedeki Kureyşîlik şartını" ${ }^{25}$, Evlilikte eşler arasındaki denklik (kefâet) öncelikle nesebde aranır, binaenaleyh Kureyş birbirinin dengidir, Araplar birbirinin dengidir; mevâlîye gelince...” şeklindeki ictihad ${ }^{26}$ ve muvâlât akdi anlayışlarındaki bazı tezahürleri burada hatırlanabilir.

Diğerlerine göre daha az gündeme geldiği için son örneği ayrıntılandıralım. Mevâlîden olan Ebu Hanîfe ve onun öğrencileri, Mâlikî ve Şâfiîlerin aksine velâu'l-muvâlât denen bir tür ferdî dayanışma akdini kabul etmişlerdir. ${ }^{27}$ Bu kabulün arkasında her ne kadar bazı sahabî görüşleri bulunuyorsa da, tarihsel ve toplumsal bir arka plan ögesi de mevcuttur ki, o da Emevî ve Abbasîlerin ırkçı politikaları karşısında mevâlîye toplumsal konum kazandırmaktır. Nitekim bu tür bir velâ sözleşmesinde, velâya tâlib olan şahsın "evlâd-ı Arabtan” olmaması şart koşulmuştur. Bunun gerekçesi de, "Araplar arasında kabile ve aşîret teşkilatı mevcut ve bu suretle aralarında tenâsur carî olduğundan muvâlât akdine hacet yoktur." ${ }^{28}$ biçiminde tesbit edilmiştir.

\section{Artık yaşamayan örflere göre verilmiş fetvâlarda.}

Karâfî (ö. 684/1285) mezhep âlimlerinin, kendi zamanlarında mevcut örf ve âdetlere bağlı olarak verdikleri hükümlerden söz ederken, şu açıklamayı yapmıştır: "Kaynağını örf ve âdetlerin teşkil ettiği ahkâm üzerinde -bu örf ve âdetler değiştiği halde- ısrar etmek ve bu ahkâmla amel etmeye devam etmek, icmâya aykırı bir tutumdur ve dini bilmemektir. İslâm hukukunda örfe bağh olarak verilmiş olan her hüküm, örf değiştiğinde yeni örfün gerektirdiği şsekilde değişir." ${ }^{29}$

Aynı konuyla ilgili olarak İbn Âbidîn de (ö. 1252/1836) şu yorumu yapmıştır:

"Pek çok hüküm, zamanın ve o zamanda yaşayan insanların örflerinin değişmesi ya da bir zaruret zuhur etmesi veya o sırada insanların bizzat kendilerinin bozulması sebebiyle değişmiştir. Öyle olmayıp da hükümler ilk şekliyle kalacak olsaydı insanlar zararla, zorlukla karşılaşırlardı. Ayrıca bu durum, hafifleștirme, kolaylaştırma ve fesat ile zararı yok etme temellerine dayalı şer'î ilkelere de ters düşerdi. İste bu sebeplerle, Ebû Hanîfe'den sonra gelen mezhebin büyük fukahâsı (meşâyıh), mezhep imamının kendi zamanındaki örfe göre benimsediği görüsslerine pek çok noktada muhalefet etmiştir. Zira onlar mezhep imamının koyduğu prensiplerden hareketle biliyorlardı ki, eğer Ebû Hanîfe kendi zamanlarında yaşasayd mutlaka onlar gibi hüküm verirdi."30

23 Tahric değerlendirmeleri için bk. Zeyla'î, Nasbu'r-râye li tahrîci ehâdîsi'l-Hidâye, Beyrut 1987, III, 197-198; İbn Hacer, ed-Dirâye fî tahrîci ehâdisîll-Hidâye (nşr. A. H. Yemânî), Beyrut, II, 63.

24 Aliyyü'1-Kârî, el-Masnû' fi márifeti'l-mevdû' (thk. A. Ebu Gudde), Beyrut 1398/1978, s. 123; Aclûnî, Keşfu'l-hafâ, II, 75.

25 bk. Hatiboğlu, M. Said, “İslamda İlk Siyasî Kavmiyetçilik: Hilâfetin Kureyşîliği”, AÜİFD, c. 23 (1978) ss. 121-213.

26 Serahsî, el-Mebsût, İstanbul 1983, V, 23; Merğînânî, el-Hidâye, İstanbul 1986, I, 201; İbn Kudâme, el-Muğnî, Beyrut 1984, VII, 28-29; Nevevî, Ravdatu't-tâlibîn, Beyrut 1992, V, 424-425.

27 Serahsî, el-Mebsût, XXX, 43; Merğînânî, age., III, 274.

28 Bilmen, Ömer Nasuhi, Hukuk-ı İslâmiyye ve Istılâhât-ı Fıkhiyye Kamusu, İstanbul ts. (Bilmen Yayınevi), IV, 69; bk. Serahsî, Şerhu's-Siyeri'l-kebîr, V, 1843,1995, Merğînânî, age., III, 274.

29 Karâfî, el-İhkâm fî temyîzi'l-fetâvâ ani'l-ahkâm ve tasarrufâti'l-kâdî ve'l-imâm (nşr. A. Ebû Ğudde), Beyrut 1995, s. 218-219; bk. a.mlf. el-Furûk, Beyrut ts. (Âlemü'l-Kütüb), I, 176-177.

30 İbn Âbidîn, “Neşru'l-arf fî binâi ba'di'l-ahkâm ale'l-urf”, Mecmûatürr-Resâil, İstanbul 1320, II, 125. 
Bu bağlamda mesela dişarıda yemek yemenin, erkekler için başı açık gezmenin, kısa kollu gömlekle dışarıda dolaşmanın şahitlik ehliyetini zedeleyeceği; evin bir odasını görmüş olmanın görme muhayyerliğini düşüreceği, sağlık harcamalarının evlilik nafakasına dâhil olmadığı, garanti belgeli satışların akdi ifsat edeceği görüşleri artık müftâ_bih sayılmayacaktır.

\section{E. Verildiği dönemdeki maslahata ve amaca artık ulaştırmayan, aksine mefsedete veya istismara yol açan fetvâlarda.}

Mesela nikâh akdinin alenîliğini temin ve tarafların haklarını ispat edip korumak amacıyla, dar toplumlarda iki şahidin bulunması yeterli görülmüştür. Fakat günümüzün kalabalık toplumlarında, bir evlilik akdinin aleniyetini sadece iki şahide bağlamak, suiistimalleri de beraberinde getirebilir. Hükmü koyarken hukuk düzeninin hedeflediği noktaya bugün, ilan ve tescil ile daha etkin bir biçimde ulaşılacağından şahitlikle beraber ilan ve tescili de öngören görüşler dikkate alınabilir.

\section{F. Toplumsal ihtiyaçları ve sorunları gidermede kendi mezhep görüşünün yetersiz kaldığı durumlarda.}

Bütün bir toplumun huzur, selamet ve bekâsını tehdit eden kimi sorunların çözümlenmesi, bazen o toplumun genel olarak benimsediği ve hukuk düzenini eksenine oturttuğu mezhebi aşmayı gerektirebilir. Böyle nazik durumlarda “zarar-1 âmmı def” ile kamu yararını tesis etmek zeminine oturan bir gerekçelendirmeyle başka mezhep hükümleri tercih edilebilir. Hanefî mezhebini imtisalde 1srarlı olan Şeyhulislâm Ebussuûd Efendi’nin, Karamanlı Şeyh münasebetiyle Osmanlı toplumunun inanç ve amel anlayışını tehdit eden "zındıklara” karşı verdiği şu fetvalarda bu tavrı açıkça görmek mümkündür:

"Mes'ele: Zındık olanın ve sebbedenin İslâmı ve tevbesi İmam-ı Âzam katında makbul olup katilden halâs olur. Şahs-1 mezkûr (Karamanlı Şeyh) mirâran tecdîd-i iman ve tevbe etmiş iken halâs olmadığının bâisi nedir?

el-Cevâb: Zındıkın tevbesi kabul olunmak kable’l-ahz vâki olıcaktır. Tutulduktan sonra vâki olan tevbeye itibar yoktur. Şahs-1 mezbûrdan ne vâki olmuştur, ba'de'l-ahz vâki olmuştur. Sebbedenin eğerçi İmam Âzam katında İslâmı ve tevbesi ile vücûb-i katl sâkıt olur, amma sâir eimme-i din katında hâli üzerine bâkidir. Kudât-1 Memâlik-i Mahmiyye, umûr-1 dinde mübâlât etmeyenlerin tevbelerine itibar etmeyüb sâir eimme mezheplerince katillerine hükmetmeye memur ve mezunlardır. Ba'de'l-hükm ol cihetten dahi vücûb-i katl ittifâkî olur.”

“Mes'ele: Bu hususta hükmeden hâkim Hanefiyyü'l-mezheb olub kendi mezhebin âmiden terk idüb sâir eimme mezhepleri ile hükm edicek, nâfiz olub bi'l-ittifak katli vacib olur mu?

el-Cevâb: İmam-ı Âzam katında tevbe ve İslâmı (ile) sâkıt olan vücûb-i katildir; cevaz-ı katil değildir. Sâir eimme reyleri ile amden katl olunmak caiz idüğ̈̈ ve hükm olunduktan sonra hatmen vacib idüğ̈̈ İmam-ı Âzam katında mukarrer ve müsellemdir. Hükm iden hâkim Hanefî olmak zarar eylemez. Hatta hâkim Hanefî müctehidi olub İmam-ı Âzam reyinin sihhatine itikad ve kuvve-i deliline kemâl-i itimad üzerine iken dahi sâir müctehidîn kavli ile amel idüb kendi mez- 
hebinin hilâfina hükm eylese İmam Eb̂̂ Yûsuf katında eğerçi hüküm nâfiz değildir, amma İmam-ı Âzamidan azhar rivâyât üzerine nâfizdir. Kibâr-ı meșâyih-i Hanefiyyeden İmam-ı celîl Ebû Bekir Muhammed b. el-Fadl el-Buhârî ve İmam-ı mecîd Sadr Şehîd bunu ihtiyar etmişlerdir. Meşâhîr-i kütüb-i fetâvâda fetvâ bunun üzerinedir."31

Norm ihtiyacını, temel felsefelerine uyan bir adalet anlayışıyla karşılayarak sosyal düzeni sağlamayı amaçlayan hukuk yapıcıları, yeni çıan ya da zamanla farklılaşan ihtiyaçları başka mezheplere müracaatla gidermek durumunda kalabilirler. Nitekim Mecelle Cemiyeti, Mecelle'nin bazı maddelerini yeniden düzenlemek ve eksikliklerini tamamlamak üzere yaptığı çalışmalarda 283. maddeyi "Cüzâfen iştirâ olunan mat'ûmât ile bunların gayrı bilcümle menkûlât ve akârın kable'l-kabz ve ba'de'l-kabz ahâra bey'i câizdir" diyerek Mâlikî görüşüne göre; 381-387. maddelerdeki hükümleri "Hayvânâtta dahi selem sahihtir. Fakat cins, sin (yaş), nevi ve sıfatın beyanı şarttır” diyerek diğer üç mezhebin görüşüne göre değiştirmiştir. Aynı amaçla kurulan Mecelle Tảdîl Komisyonu, çeşitli mezheplerden günün ihtiyacına en uygun ictihadları tercih etmeyi ilke edinmiştir. ${ }^{32}$

Yine bu ilkeden hareketle mesela şöyle bir değerlendirme yapılabilir: Aynı anda veya mecliste verilen üç talâkın geçerli olacağı hükmü, günümüzde geçmiş zamanlara göre çok daha önemli hale gelen aile kurumunu ve çocukları korumada telafisi güç açıklar meydana getirmektedir. Ayrıca Allah Resûlü’nün lanetlediği bir rezalet olan anlaşmalı hülle evliliklerine kapı açacağından büyük mefsedetlere de sebep olmaktadır. Öyleyse hem delilinin mevcudiyeti, hem de aileyi koruyucu yönü dikkate alınarak aynı anda vaki olan üç boşamayı bir boşama olarak değerlendiren görüş dikkate alınabilecektir.

Aynı şekilde Ebû Hanîfe’nin, ödeme gücü bulunduğu halde borcunu geciktiren veya borçlarını ödeyemez duruma düşen kimsenin hacr altına alınamayacağı yani malî tasarruf ehliyetinin kıstllanamayacağı; borcunu ödemeye zorlamak için sadece hapsedilebileceği, cebrî icra takibi yapılamayacağı şeklindeki görüşü̉33, hem zaten fazlasıyla dolu olan ceza ve tutuk evlerinin istiabını zorlayacak hem bunların bakım masrafları açısından devlete ilave külfetler yükleyecek hem de mütemerrid borçluları yeterince caydırmayacaktır. Öyleyse günümüz şartlarıyla daha uyumlu olduğu için hacr ve ardından cebrî icra hükümlerini öngören ictihadlar tercih edilebilecektir. Nitekim Mecelle-i Ahkâm-1 Adliyye’nin konuyla ilgili maddeleri (md. 998-1002) buna göre düzenlenmiştir. Kaldı ki tercih edilen bu hüküm, Hz. Peygamber ve Hulefâ-yi Râş̧idîn tatbikatıyla $\mathrm{da}^{34}$ uyumludur.

1880 yılında Mısır'da çıkarılan bir Lâyiha’nın, düzenlemelerin Hanefî mezhebinin râcih görüşüne göre yapılacağını öngörmekle beraber, cinayet/katl davalarını fesâdü’z-zamân gerekçesiyle diğer üç mezhebin hükümleri doğrultusunda sonuçlandırmasını ${ }^{35}$, bir başka örnek olarak kaydedebiliriz.

31 Düzenli, Șeyhulislâm Ebussuûd Efendi ve Fetvâları, s. 371-372.

32 Karaman, Hayreddin, İslâm Hukuk Tarihi, İstanbul 1989, s.335-336; ayrıntılar için bk. Kaşıç̧ı, Osman, İslâm ve Osmanlı Hukukunda Mecelle, İstanbul 1997, s. 307-384.

33 Merğînânî, el-Hidâye, III, 104, 285.

34 Müslim, "Müsâkāàt", 18, 22-24.

35 Merâğî, Muhammed Mustafa, el-İctihad fi'l-İslâm, Kahire 1959, s. 53. 


\section{G. Zaruret ve mübrem ihtiyaç bulunduğunda.}

Gerek zaruretin ve mübrem ihtiyacın gerçekten sübut bulup bulmadığı konusundaki endişeler, gerek dindarlık ölçütleri ve gerekse karşılaşılan istisnaî durumun kural haline gelmesi/getirilmesi riski bu noktada itirazlara kapı aralamaktadır. Fakat hiç istenmeyen ve gerçekten istisna düzeyinde karşılaşılan fevkalâde durumlarda, müsteftînin problemini, hukukun tanıdığı meşru çerçevede çözümlemek ve son tahlilde "pamuk ipliğiyle" bile olsa kişileri inandıkları sisteme bağlı tutmak da önemli bir konudur. İşte böyle bir durumda, müftînin ve müsteftînin mezhebinde, badireyi atlatacak bir çözüm bulunamadığında başka mezheplere müracaat söz konusu olabilecektir. Nitekim bazı âlimler, zaruret ve ciddi ihtiyaç bulunması halinde başka mezheple amel edilebileceğini ve fetvâ verilebileceğini kabul etmişlerdir. ${ }^{36}$

Hanefî âlimi Fahru'l-İslâm Pezdevî̀den (ö. 482/1089) nakledilen “Zaruret bulunan yerlerde şayet kolaylaştırmayı hedefleyerek zayıf görüßslerden birisiyle fetvâ verilirse bu, güzel bir davranış olur." sözü, zorda kalındığında başka mezheplerin hükümlerinden de istifade edilebileceğine $1 s ̧ ı k$ tutmaktadır. İbn Âbidîn de (ö. 1252/1836), "Müftînin zayıf görüşlerle gerek amel etmeye gerekse fetvâ vermeye yetkisi yoktur" sözünü, "Bu kural, zaruret hallerinin dişında geçerlidir" diyerek kayıtlamıştır. ${ }^{37}$

Mesela daha önce iki talâkları gerçekleşmiş olan bir karı-koca arasında, bu defa "Eğer onunla konuşursan boş ol!" tarzında bir konuşma geçse ve ardından kadın da o kişiyle konuşsa acaba üçüncü talâk da vaki olmuş olur mu? Talâkın, bu örnekte olduğu gibi bir başka fiile bağlanması (ta'lîku’t-talâk, muallak talâk) ve bunun gerçekleşmesine göre evliliğin de sona ermesi (vukû̉ ûttalâk) çoğunluk tarafından kabul edilmiştir. Buna karşılık Hz. Ali, Hz. Âişe, Kadı Şüreyh, İkrime ve Tâvûs, böyle bir işlemi yemin kabul ederek boşama kapsamında değerlendirmemişlerdir. Hatta kendisinden yapılan bir nakle göre İmam Şâfiî; Süfyân es-Sevrî, Kaffâl, Hanefîlerden Tahâvî, Mâlikîlerden Eşheb gibi bazı fakihler ve Zâhirîler, Kurân ve Sünnet'in belirlediği boşama süreç ve şekillerine uymadığı gerekçesi ile şarta bağlı talâkın ve talâka yapılan yeminin geçersiz olup hiçbir sonuç doğurmayacağını kabul etmişlerdir. ${ }^{38}$ İbn Teymiyye ise kocanın niyetine göre karar verileceğini söylemiştir. Yani yemin kastı varsa yemin, talâk niyeti varsa talâk hükümleri söz konusu olacaktır. ${ }^{39}$ İmdi yukarıdaki evliliğin dönülemez biçimde bütünüyle bitmesi (beynûnet-i kübrâ), küçük çocukların mahrumiyetlerle karşılaşması, kadının kimsesiz kalması, çok çirkin bir uygulama olan danışıklı "hulle" ihtimalini gündeme getirmesi gibi sonuçlar doğuracaksa, bu soruyla karşılaşan müftînin, kocanın niyetine başvurması ve eğer boşama kastı yoksa dört mezhebin de dışına çıkıp konuyu talâk değil, yemin kapsamında değerlendirmesi yerinde olacaktır.

\section{H. Mezhebinin görüşünün yanlış bir bilgiye dayandığı veya bilimsel bilgiye aykırı olduğu durumlarda.}

Önceden doğru kabul edilen ama bilim ve tekniğin gelişmesiyle yanlış olduğu ortaya çıkan beşerî bilgilere dayalı hükümler, bilimin istikametinde gözden geçirilir. Bu yaklaşım, bilimsel

36 Karadâvî, İslâm Hukuku, s. 106; Nakîb, Ahmed b. Muhammed, el-Mezhebü'l-Hanefî, Riyad 2001, I, 271, 273.

37 Her iki yaklaşım için bk. İbn Âbidîn, "Şerhu'l-Manzûmeti'l-müsemmât bi Ukûdi Resmi'l-müftî”, I, 35, 49.

38 Cassâs, Muhtasaru İhtilâfi'l-ulemâ, Beyrut 1417, II, 438; İbn Hazm, el-Muhallâ, Beyrut 1988, IX, 477-479; İbnü'lKayyım, I’lâmu'l-muvakkı̂n, IV, 74-78; Abdulkerim Zeydân, el-Mufassal fì ahkâmi'l-mer'e, Beyrut, 1993, VII, 471-473.

39 İbn Teymiyye, Mecmûatü'l-fetâvâ, (nşr. A. Cezzar-E.Baz), Mansura 2005, XXXIII, 82-83. Konuyla ilgili ayrıntılar için bk. Din İşleri Yüksek Kurulu’nun 2014/21 nolu Mütalaası; Okur, Kâşif Hamdi, "İslâm Hukukunda Boşama Yemini (Talâka Yemin) Meselesi", Hitit Üniversitesi İlahiyat Fakültesi Dergisi, sy. 15 (2009/1), ss. 5-30. 
bilginin dinî bilgiyi yönlendireceği biçiminde anlaşılmamalıdır. Burada söz konusu olan husus, yanlış bilimsel bilginin doğrusu ile yer değiştirmesidir. Mesela ceninin canlılığının dördüncü ayda başlayacağı, hamileliğin 2 ya da 5 yıla kadar uzayabileceği, yaraya konulan ilacın dimağa ulaşacağı, vücuda yapılan enjeksiyonun veya abartılı istincâ sırasında anüsden giren su damlalarının mideye gideceği yönündeki tespitler ve bunlara bağlı hükümler gözden geçirilmelidir.

Aynı şekilde, içine taze balık veya ekmek atılmak suretiyle hamrın sirke haline getirilebileceği ictihadı (zira günümüz bilimine göre böyle yapmakla alkol sirkeye dönüşmez), suyun bulunamadığı zaruret halinde susuzluğu gidermek için içki içilebileceği fetvâsı (zira bilimsel bilgiye göre bu durumda ölüm daha da hızlı gerçekleşir), sigaranın mubah veya tenzihen rnekruh olduğu kanaati de bu başlık altında ele alınabilecek örneklerdir. ${ }^{40}$

I. Kitlesel olarak çok zor durumda kalınıp başka mezheplerde bu zorluğu gideren ve ümmeti rahatlatan çözümlerin bulunması halinde.

Bu madde özellikle hac ibadeti sırasında daha işlevsel olmaktadır. Milyonlarca müslümanın hac menâsikini kimseye zarar vermeden ama usûlünce eda edebilmeleri için mesela Arafat'tan akşam ezanından önce ayrılmaya cevaz veren Şâfiî görüşünü, Müzdelife'de gecelemeyi şart görmeyen Mâlikî görüşünü Arefe gününü bayrama bağlayan gece yarısından itibaren Akabe cemresine taş atmayı ve ifâda tavafını yapmayı onaylayan Şâfiî ve Hanbelî görüşünü, taş atma günlerinde Mina’da kalmayı şart (vacip) koşmayan Hanefî görüşünü, zevalden önce şeytan taşlamaya, kendisinden yapılan bir rivayete göre cevaz veren Ebû Hanîfe’nin görüşünü uygulamak bu ilkeye örnek verilebilir.

Burada şunun altı çizilmelidir ki, yukarıdaki gerekçelere bağlı olarak bir başka mezhebin çözümünü tercih etmek, müftînin liyakati ve ilmî donanımı ile yakından ilgilidir. Hem kendi mezhebinin dayanaklarını hem de tercih edeceği mezhebin gerekçelerini metodolojik bir bakışla tahlil edebilen; bunun yanında muhatap olduğu olay, mesele ya da olgunun künhüne vâkıf olabilen müftînin bu yeterliliğe sahip olduğu söylenebilir.

\section{İ. Müslüman devlet başkanının bir konuda diğer mezhebe veya kendi görüşüne göre hüküm verilmesini emretmesi halinde.}

İslâmî duyarlılıkları olan merkezî otoritenin bu emri karşısında müftî, işaret edilen görüş eğer kat'î delillere açık bir aykırılık taşımıyorsa, kendi mezhebinin dışına çıkacak ve gösterilen hüküm ile fetvâ verecektir. Gördüğ̈̈ maslahat üzerine devlet başkanının böyle bir tasarrufta bulunmasını, âlimler öteden beri onaylaya gelmişlerdir. ${ }^{41}$ Ebû Yûsuf'un (ö. 182/798) Halife Harun er-Reşid’e hitaben yazdıkları, bu onayın ilk örneklerinden biridir: “Ey müminlerin emiri! Bu iki görüşten sence daha isabetli olanını tercih et ve müslümanların yararına en uygun ve sonuçları itibariyle en hayırlı olduğuna inandığını uygula. Çünkü Allahın izniyle senin buna yetkin vardır." ${ }^{2}$ İmam Şâfî̂̀nin (ö. 204/820) şu cümleleri, devlet yöneticilerinin tercihlerinin özel bir yeri olduğuna işaret eder: "Devlet başkanının sözü insanları bağlar. Sözü insanları bağlayan kimsenin gö-

40 Bk. Yaman, Ahmet, "Fıkhın Sosyolojik Yürürlüğü Bağlamında Fetvâda Değișim”, Diyanet İlmi Dergi, 50/2 (2014), s. 18.

41 Karâfî, el-İhkâm, s. 184; Seyyid Bey, age., s. 315; Küçük Hamdi (Elmalılı), "Makâle-i Mühimme”, Beyânülhak, I/18,

İstanbul 1324, s. 403-404; Merâĝ̀̂, el-İctihad fi'l-İslâm, s. 35; krş. Mâverdî, Edebü’l-kâdî, I, 187-189; Aşkar, Muhammed

Süleyman, el-Fütyâ ve menâhicü'l-iftâ, Kuveyt 1976, s. 102-103.

42 Ebû Yûsuf, Kitabü'l-Harâc, s. 19, 95. 
rüşü, başka müftînin görüşünden elbette daha meşhur ve baskındır. Zira soru soran kişi, o müftînin fetvâsını benimseyebileceği gibi terk edebilir de. Müftîlerin pek çoğu evlerinde veya bulundukları meclislerde kendilerine başvuran belli kimselere fetvâ verirler. Toplum bunların fetvâlarını, imamın görüşleriyle aynı önem derecesinde görmez." 43 Serahsînin (ö. 483/1090) ifadeleriyle de "İctihadî konularda devlet başkanının hükmü geçerlidir"44; "Yöneticinin verdiği emir, mevcut ictihadî çözümlerden birine uygun ise geçerlidir" ${ }^{45}$

Aynı mesele Mecelle Mazbatası'nda "Mesâil-i müctehed_fîhâda, Imamu’l-müslimin hazretleri, herhangi kavil ile amel olunmak üzere emreder ise mûcebince amel olunmak vacip olduğundan" biçiminde ifade edilmiş, 1801. maddenin altında, bunun ne derece bağlayıcı olduğu şu cümle ile izah edilmiştir: "Bir müctehidin bir hususta reyi, nâsa erfak ve maslahat-1 asra evfak olduğuna binaen, ânın reyi ile amel olunmak üzere emr-i sultânî sâdır olsa ol hususta hâkim ol müctehidin reyine münâfi diğer bir müctehidin reyi ile amel edemez. Ederse hükmü nâfiz olmaz".

Böyle bir yetki, ülkede hukuk güvenliğinin sağlanması bakımından da anlamlı ve işlevsel görünmektedir.

İbn Abbas'ın (r.a.) ve Kadı Şüreyh’n şu uygulamaları, bu ilkenin birer örneği olarak hatırlanabilir: Aynı anda verilen üç talâkın tek sayılacağı görüşünde olup, aynı zamanda bu hükmü taş1yan hadisin de râvîsi olan İbn Abbas, Hz. Ömer’in (r.a.), gördüğü lüzum üzerine bunu üç sayması kararından sonra kendi kanaatiyle değil, devlet başkanının tercihiyle fetvâ vermeye başlamıştır.

Müslümanın kâfire mirasçı olamayacağı kanaatinde olan ve bu yönde karar veren Kadı Şüreyh (ö. 78/697), Muâviye’nin aksi yöndeki talimatını alınca merkezî yönetimin tercihi doğrultusunda karar vermeye başlamış ve her defasında da "Bu, mü’minlerin emîrinin hükmüdür" diyerek, aslında aynı düşüncede olmadığını ıhar etmiştir. ${ }^{46}$

Benzer şekilde Hz. Ömer'in müt'atü'l-hacca yani hac aylarında, iki ayrı ihramla umre ve hac yapmak demek olan temettû haccına izin vermemesi ile ehl-i kitap hanımlarla evlenmeyi yasaklaması da bu kapsamda değerlendirilebilecek örneklerdir. Onun bu kararından sonra müftîler belli bir süre aksine görüş beyan etmemişlerdir.

Müftî farklı kanaatte olsa bile, devlet başkanının tercihine uyması gerektiği konusunda Abdullah b. Mes'ûd'un gösterdiği şu hassasiyet anlamlı görünmektedir: İbn Mes'ûd Mina'da namazların kasredilerek (kısaltılarak) kılınması gerektiği görüşündeydi. Hz. Osman namazları orada kasretmeksizin tam olarak kıldırınca, İbn Mes'ûd buna itiraz etmiş, fakat ardından da ona uyarak tam kılmıştı. Kendisine, hem itiraz edip hem de niye tam kıldığı sorulunca İbn Mes'ûd “Karşı çıkmak daha kötü sonuçlar doğurur" cevabını vermiştir. ${ }^{47}$

Öyleyse, İslâm öğretisini benimseyip buna göre faaliyet icra eden devlet mekanizmasının çıkardığı mevzuatın bulunması durumunda müftî, artık kendi mezhep görüşüne ya da tercih ettiği görüşe göre değil bu mevzuata göre fetvâ verecektir. Mevzuatın dört mezhebin dışında bir

43 Şâfiî, el-Üm, Beyrut 1993, VII, 452.

44 Serahsî, Şerhu's-Siyeri'l-kebîr, (thk. S. Müneccid - A. Abdülaziz), Kahire 1958-1971, IV, 1544.

45 Serahsî, age., V, 2189.

46 Şa’bî kaynaklı bu bilgi için bk. Cassâs, Ahkâmu'l-Kurân, Beyrut 1993, II, 146.

47 Ebû Dâvûd, "Menâsik", 75; Müsned, V, 165. 
görüşü benimsemiş olması, aşağıda ayrıca ele alınacağı üzere, mümkün ve meşrudur. Böyle olması müftîye kanun karşısında daha rahat bir hareket alanı sağlamaz. Mısır Müftülerinden (Müftî Diyârı Mırr) Abdülmecid Selim’in (ö. 1954) 25 Mart 1930 tarihli şu fetvâsı, bu keyfiyetin somut bir örneğidir:

"Bir erkek 'hangi türü olursa olsun sarhoşluk verici içki içersem eşim bana, tıpkı annem ve kızkardeşim gibi haram olsun' diyerek talâkı bir fiile bağlar ve daha sonra o fiili yaparsa Hanefî mezhebine göre bir bâin talâk meydana gelir. Fakat yürürlükte olan 1929 tarih ve 25 numaralı kanuna göre, bu sözü söylemekten kasdı boşamak değil de kendisini içkiden alıkoymaya zorlamak ise, boşama gerçekleşmez. Boşama kasdıyla söylemişse yine zikri geçen kanuna göre bir rac'î talâk meydana gelmiş olur." ${ }^{48}$

Bu noktada belirtilmelidir ki, kendi mezhebi dışında yukarıdaki gerekçelerden birisine bağlı olarak başka bir mezhebin görüşünü tercih ederek onunla fetvâ veren müftînin, bu durumu müsteftîye bildirmesi yerinde olacaktır. Zira çoğu müsteftî, belli bir mezhep hassasiyetine sahiptir. Dolayısıyla hangi mezhepten olduğunu bilerek ve o mezhebin hükmünü öğrenmek amacıyla bir müftîye danışır. Önde gelen Şâfiî fakihlerinden Ebû Bekir el-Kaffâl el-Mervezînin (ö. 417/1026) şu sözü bu duyarlılığa işaret etmektedir: "Eğer ictihadım beni, Ebû Hanîfe'nin mezhebini tercihe götürürse muhatabıma 'Şâfiî̀nin mezhebi şudur, ama ben Ebû Hanîfe’nin görüşüyle hüküm veriyorum' derdim. Zira o kişi bana, Şâfiî̉nin mezhebini öğrenmeye geliyordu. Bu durumda benim, başka birisinin görüşüyle fetvâ verdiğimi ona bildirmem gerekiyordu." ${ }^{9}$

Diğer taraftan dindarlık ölçütü olarak belli bir mezhep çerçevesini benimseyen ve buna bağlı olarak dindarlığını belli bir mezhep sistematiği içinde kalarak sürdürmek isteyen kişilerin anlayışlarına saygılı olmak gerekir. Karâfî̀nin ve İbnü'l-Kayyım’ın cümleleriyle "Mâlikî bir müftîye gelip 'Ben Şâfiîyim; şu konuda Mâlik'in görüşü nedir ve bu beni bağlar mı?' sorusunu yönelten müsteftîye, Mâlikî mezhebine göre cevap verilmesi doğru olmaz." ${ }^{50}$; Belli bir imama müntesip olan müftîye 'Şu konuda Şâfiî̀nin mezhebi nedir?' diye sorulsa, o müftî başka bir görüşü değil ancak Şâfiî̀nin görüşünü nakledebilir”. ${ }^{51}$

\section{Dört Mezhebin Dışına Çıkmak}

Hukukî hayatın belli bir mezhebe göre düzenlendiği klasik dönemlerde, müftînin, yetkin bir müctehid derecesine ulaşmış olsa bile, benimsenen mezhebin dişına çıkmaması gerektiği vurgusunun sık yapıldığg bilinmektedir. ${ }^{52}$ Hanefî âlim Kâdîhân el-Özcendînin (ö. 592/1196) koyduğu “Zamanımızın Hanefî müftîlerine bir mesele hakkında fetvâ sorulduğunda, şayet o konuda bizim imamlarımızdan Zâhiru'r-rivâye'de ihtilafsız bir nakil varsa, müftî, iyi bir âlim ve müctehid bile olsa ona aykırı bir fetvâ veremez. Çünkü doğru/hak, bizim önderlerimizle beraber olup onları aşmaz; müftînin ictihaddaki derecesi de onların derecesine ulaşamaz" ${ }^{53}$ kuralı, bu yaklaşımın tipik bir örneğidir.

48 el-Fetâvâll-İslâmiyye min Dâri'l-İftâi'l-Misriyye, Kahire 2010, XI, 95.

49 İbnü's-Salâh, Edebü'l-müftî ve'l-müsteftî, s. 59; İbn Hamdân, Sıfatü’l-müftî, s. 39; İzmirli, İlm-i Hılâf, s. 293. Biraz farklı bir anlatım için bk. Zerkeşî, el-Bahru'l-muhît, VI, 296.

50 Karâfî, el-İhkâm, s. 230.

51 İbnü'l-Kayyım, İlâmu'l-muvakkıîn, IV, 181; bk. Telkenaroğlu, Tevcîhü'l-halef, s. 200.

52 Mesela bk. Gazzâlî, el-Müstasfâ, Beyrut 1993, s. 368; Kâdîhân, el-Fetâvẩl-Hâniyye, I, 2; bu yaklaşımın çağdaş birer savunusu olarak bk. Bûtî, M. Saîd Ramadan, el-Lâmezhebiyye, Beyrut 1996; Mekkî, Muhammed b. Ali, Davâbitu'l-fetvâ, İskenderiye 1418 .

53 Kâdîhân, el-Fetâvâ’l-Hâniyye (el-Fetâvâll-Hindiyye’nin kenarında), Bulâk 1310, I, 2. 
Aynı dönemlerde, diğerlerinin görüşlerinin tam ve güvenilir olarak tedvin edilmediği gerekçesiyle dört mezhebin dişına çıkılmaması gerektiği de bazı âlimlerce dile getirilmiştir. ${ }^{54}$ Hatta dört mezhepten birisine mensup olmakla birlikte "müctehid" derecesine yükselmediğine inan1lan fakihlerin münferit görüşlerinin bile muteber sayılmayacağı söylenmiştir. Mesela Ebussuûd Efendi’nin şu cümlesi de bu tavrın bir yansımasıdır: “... Mesâil-i ictihâdiyyede müctehidden gayrı, İmam Gazzâlî ve ânın emsâli kimesnelerin kavillerine itimad câiz değildir”. ${ }^{5}$

Bununla birlikte çerçeveyi biraz genişleterek Evzâî (ö. 157/774), Süfyân es-Sevrî (ö. 161/778), İshâk b. Râhûye (ö. 238/853), Ebû Sevr (ö. 240/854), İbn Cerîr et-Taberî (ö. 310/923) ve bazı itirazlar olsa da Dâvud b. Ali ez-Zâhirî̀yi de (ö. 270/884) taklid edilebilecekler listesine alanlar olmuştur. ${ }^{56}$

Fakat doğrunun sadece bilinen dört mezheple sınırlı kalamayacağı, fıkıh mirası içinde pek çok mezhep ve müctehidin bulunduğu ve esasen fikıh doktrininin de bunların katkılarıyla derinlik kazanıp mükemmelleştiği de bir gerçektir. Son dönem Osmanlı âlimlerinden Mehmed Seyyid Bey’in (ö. 1924) ifadesiyle:

“Taklit ehli için herhangi bir müctehidi taklit caizdir... Bu hususta hiçbir müctehidin imtiyaz hakkı yoktur. Böyle bir iddiada bulunan bir müctehit de zuhur etmemiştir. Bu husus böyle olmakla beraber pek açıktır ki, bir meselede bir müctehidi taklit edebilmek, onun fikriyle amel edebilmek için her şeyden evvel o müctehidin o mesele hakkındaki fikrini bilmek lazımdır. Fikri mâlum olmayan bir müctehidi taklit etmek tasavvur edilemez. Bir müctehidin bir mesele hakkındaki fikrini bilmek ise ancak iki yoldan biriyle mümkün olabilir. Bunun üçüncü bir yolu yoktur. Biri, mevsûk ve mutemet bir kitapta meşhur olması, diğeri müteselsil ve muttasıl rivayet ile o müctehitten nakledilmiş bulunmasıdır... Bir müctehidi taklidin caiz olması için o müctehidin bütün meseleler hakkında tedvin edilmiş mezhebinin bulunması şart değildir." ${ }^{57}$

Öyleyse metodolojik bir tavır ve ilkesel bir yaklaşım çerçevesinde fıkıh mirasının bütününden faydalanmak mümkün olabilmelidir. Yûsuf Karadâvînin diliyle "Bazı hallerde dört mezhebin ve cumhurun görüşünün dışına çıkmamız gerekebilir. Gerçek şu ki, çoğunluğun kanaati ve tanınmış olan görüş her zaman doğru, azınlığınki de her zaman yanlış demek değildir. Bazen bir imam, ictihadında yalnız kalabilir de zaman onun görüşünün doğruluğunu ispat eder." ${ }^{38}$

Nitekim son yüzyıldaki birçok kanunlaştırma ve kurumsal iftâ faaliyetlerinde, dört mezhebin dışında kalan birçok mezhep ve müctehidin görüşlerinden de istifade edilmiştir. Mesela 1917 tarihli Osmanlı Hukuk-1 Aile Kararnamesi’nde, küçüklerin evlendirilmesine ilişkin 6. madde, dört mezhebin dışında İbn Şübrüme (ö. 144/761) ile Ebû Bekr el-Esam’mın (ö. 200/816) ictihadlarına göre düzenlenmiştir. Zâhirî mezhebinin müellif imamı İbn Hazm’ın (ö. 456/1064) yakın akrabaya

54 İbnü's-Salâh, age., s. 141-142; Nevevî, Âdabü'l-fetvâ, s. 76; İbn Nüceym, age., VI, 292; Şahin, Osman, İslam Hukukunda Fetvâ Usulü, (doktora tezi 2002), Ondokuz Mayıs Üniversitesi, Samsun, s. 146-147; Telkenaroğlu, Tevcîhü’-halef, s. 108.

55 Düzenli, Şeyhulislâm Ebussuûd Efendi ve Fetvâları, s. 371.

56 Zerkeşî, el-Bahru'l-muhît, VI, 290.

57 Seyyid Bey, Usûl-i Fıkıh: Medhal, I, 317-318, 327. Benzer bir yorum için bk. Merâğî, el-İctihad fi'l-İslâm, s. 30.

58 Karadâvî, İslâm Hukuku, s. 170; benzer bir yaklaşım için bk. Aşkar, el-Fütyâ ve menâhicü’l-iftâ, s. 35. 
vasiyeti gerekli gören reyinden hareketle, dede yetimine vasiyetin vacip olacağı yönündeki ictihad, Mısır ve Suriye başta olmak üzere pek çok müslüman ülkenin ahvâl-i şahsiyye kanunlarında benimsenmiştir. Yine dört mezhepte bulunmadığı halde, bir defada verilen üç talakın bir sayılacağ 1 , kişinin bir kimseyi herhangi bir şeye teşvik ya da herhangi bir şeyden alıkoymak maksadıyla sarf ettiği talâk sözünün (muallak talâkın) boşanmayı meydana getirmeyeceği ${ }^{59}$ şeklindeki selef görüşleri Mısır'da ve diğer yerlerde hazırlanan aile hukuku kanunlarında yer almıştır.

Dahası, Ebû Zehra’nın (ö. 1974) bildirdiğine göre Hârîcîliğin en ılımlı kolu olan İbâdıyye’nin miras hukukuyla ilgili bir ictihadı, Mısır kanunlarında tercih edilmiştir. ${ }^{60} \mathrm{Bu}$ son örnek, Ehl-i Sünnet dışında kalan bir mezhep ictihadının tercih edilmesi açısından ayrıca dikkat çekmektedir.

Sahabe ve tâbiîn fikhına bakıldığında, kabule şayan olup sırf dört mezhepten biri benimsemedi diye atılmaması gereken nice görüşlerin olduğunu söyleyen Yûsuf Karadâvî, kendisinin bu kapsamda yaptığı bir tercihi örnek olarak kaydeder: “İbn Mes’ud, İbn Abbas, Muâviye, tâbiîn ve tebe-i tâbiînden nakledilen, "Kazanılan mal (ve paranın), üzerinden bir yıl geçmesi şartı aranmaksızın, ele geçirilir geçirilmez zekâtının verilmesi gerekir” şeklindeki görüşü bu türdendir. Dört mezhepçe alınmayan bu ictihadı ben "Fılkhu'z-Zekât" isimli kitabımda tercih ettim ve bunu, maaş ve benzeri şeylerin (işçi ücretleri ve serbest meslek erbabının kazançları vb.) zekâtının alınmasında esas aldım. Yani bu paralar nisaba ulaşmışlarsa, elde edilir edilmez zekâtları verilir veya iktisatçıların dedikleri gibi daha kaynağındayken zekâtı tahsil edilir”. ${ }^{61}$

\section{Mezhep İçi Tercih}

Yukarıdaki ilkeler doğrultusunda ele alınabilecek bir diğer konu da mezhep içi tercihtir. Yine metodolojik ve olgusal gerekliliklere bağlı olarak müftî, kendi mezhebi içindeki görüşlerden birisini tercihle fetvâ verebilecektir. Fıkıh literatüründe niteliği ve içeriği tartışılır kavramlar olmakla birlikte Hanefîlerde "ashabu’t-tercîh", diğer bazı mezheplerde "el-müctehid fi'l-fetvâ" seviyesine ulaşmış fakihlere bu yetki tanınmıştır. ${ }^{62}$

Mezhebin istikrar bulmasından sonra yetișen Hanefî fakihleri, zamanın, örfün, maslahatın değişmesine bağlı olarak, mezhep imamlarının görüşleri arasından, içinde yaşadıkları zamana ve toplumsal şartlara daha uygun buldukları görüşü tercihte bir tereddüt göstermemişlerdir. Hatta gerektiğinde mezhebin ikinci halkasındaki önderlerin görüşlerinden de istifade edilmiştir ki, mesela sonraki Hanefîlerce on yedi yerde İmam Züfer'in (ö.158/775) görüşü benimsenmiştir. ${ }^{63}$

Mecelle-i Ahkâm-ı Adliyye mazbatasındaki şu cümleler, mezhep içi tercihin hem varlığına hem de gerekçesine işaret etmektedir: "Elhâsıl bu Mecelle’de mezheb-i Hanefînin haricine çıkılmayıp mevâdd-1 mündericesinin ekserisi elhâletü hâzihî Fetvâhâne muteber ve ma’mûlün bih

59 İslam hukukuna dayanarak hazırlanmıș bulunan Mısır (1929 tarih ve 25 sayılı kanun), Ürdün (2010 tarih ve 87 sayılı kanun), Kuveyt (2007 tarih ve 105 sayılı kanun), Fas (2010 tarih ve 93 sayılı kanun), Irak (36 numaralı kanun), Suriye (173 numaralı kanun) ve Suudi Arabistan (85 numaralı kanun) mevzuatında şartlı (muallak) boşamaların yemin kapsamında değerlendirileceği hükmü açıkça yer almıştır. Diyanet İşleri Başkanlığı Din İşleri Yüksek Kurulu da 2014/21 sayılı Mütalaasında aynı yönde kanaat serdetmiştir.

60 Ebû Zehra, İslâmda İtikadî Siyasî ve Fikhî Mezhepler Tarihi (çev. S. Kaya), İstanbul ts. (Yenişafak), s. 81-82.

61 Karadâvî, age., s. 171.

62 Bilmen, Ömer Nasuhi, Hukuk-ı İslâmiyye ve Istılâhât-ı Fıkhiyye Kamusu, VIII, 259, 260; krș. Kâdîhân, el-Fetâvâ'l-

Hâniyye, I, 2.

63 Bilmen, age., VIII, 259. 
olduğu cihetle bunlar hakkında bahse lüzum görülmez. Fakat yine fukahâ-yı Hanefiyyeden bazı fuhûl-i eimmenin akvâl-i mu'teberesi nâsa erfak ve maslahat-1 asra evfak olmak hasebiyle ihtiyar olunmuş idüğünden bunların meâhiz-i makbule ve esbâb-1 mûcibesi ber-vechi âtî beyan olunur."

Mezhep içi tercihi, fıkıh tarihinin önemli bir halkasını teşkil eden Osmanlı tecrübesinden örneklerle somutlaştırabiliriz:

Hanefî mezhebinde kızların evlenmesinde velinin onayını şart koşmayan İmam Ebû Hanîfe ve Ebû Yûsuf'un (ö. 182/798) görüşü istikametinde fetvâ verile gelirken Osmanlı Şeyhulislamı Ebussuûd Efendi, 951/1544 yılında çıkardığı bir genelge ile bundan böyle İmam Muhammed'in (ö. 189/804) ictihadı esas alınarak velisiz nikâhların onaylanmayacağını bildirmiştir. ${ }^{64}$ Yine Ebussuûd Efendi, gayr-1 menkul mülkiyeti ile ilgili bir meseleyi cevaplarken uygulamada eşine az rastlanır bir tutumla Ebû’l-Hasen el-Kerhînin (ö. 340/952) görüşünü tercih etmiştir. ${ }^{65}$

Şeyhulislâm Çatalcalı Ali Efendi’nin (ö. 1103/1692) şu fetvâsı bir başka örnek olarak kaydedilebilir:

"Mes'ele: Vişnâb dimekle mâruf olup müskir olan şerbetin sekir virmeyecek miktarın telehhi kasdınsız içmek helal midir?

el-Cevâb: İmam-ı Âzam ve İmam-ı Ebû Yûsuf katlarında helaldir. İmam-ı Muhammed katında haramdır. Fî zemânina İmam-ı Muhammed kavliyle iftâ ihtiyar olunmuştur." "66

Mecelle-i Ahkâm-1 Adliyye'nin, bir anda değil de peyder pey çıan meyve-sebzenin (mütelâhıku'l-vürûd) tamamının satımını düzenleyen 207. maddesi ile istısnâ (sipariş) akdinin lüzûmunu (bağlayıcılığını) düzenleyen 392. maddesinin gerekçeleri de, üzerinde bulunduğumuz hususa çok güzel bir örnek teşkil etmektedir:

"Yüz doksan yedinci ve iki yüz beşinci maddeler mûcebince madûmun bey’i sahih değildir. Hâlbuki gül ve enginar gibi şükûfe ve sebze-meyve mahsulat1, mütelâhıku'l-vürûd olarak bazı efrâdı zuhûr etmeden diğer bazı efrâdı husûle gelip geçer olduğu cihetle ekseriya bu misillûlerin zuhûr etmiş ve edecek olan mahsulatı toptan olarak satılmak örf ve âdet olmuştur ve bu misillû mahsulatta mevcuda tebean ma'dûmun dahi beraber olarak toptan satılmasını İmam $\mathrm{Mu}$ hammed b. Hasen eş-Şeybânî rahmetullahi aleyh hazretleri istihsânen tecviz buyurmuş ve İmam Fazlî, Şemsüleimme Halvânî ve Ebû Bekir b. Fazl rahmetullahi aleyhim ânın kavliyle iftâ etmiş olduklarından ve nâsı bu misillû örf ü âdetlerinden geçirmek kâbil olamayıp hâlbuki muâmelât-1 nâsı fesâda nisbetten ise mehmâ emken sihhate hamletmek evlâ olduğundan bu Mecellède dahi kavl-i Muhammed bi’t-tercîh iki yüz yedinci madde âna muvafik olarak yazılmıştır."

\footnotetext{
64 Ebussuûd, Ma’rûzât, (haz. Pehlül Düzenli), İstanbul 2013, s. 73-74: "Sene ihdâ ve hamsîn ve tis'i mie tarihinde kudât, velî izninsiz nikâhı kabul itmemekle memurlardır...”

65 Bk. Düzenli, Şeyhulislâm Ebussuûd Efendi ve Fetvâları, s. 386.

66 Fetâvâ-yı Ali Efendi (haz. Salih el-Kefevî), İstanbul 1311, II, 246-47.
} 
“İmam-1 Âzam hazretlerinin indinde istısnâen mün’akid olan bey'den müstasni rücu edebilir ise de İmam Ebû Yûsuf rahmetullahi aleyh hazretlerinin indinde masnû, tarife muvâfik olduğu halde rücu edemez. Şimdi ise âlemde pek çok kârgâhlar yapilarak bunca toplar ve tüfekler ve vapurlar mukavele ve sipariş ile yaptırılagelip istısnâ keyfiyet-i mesâlih-i cesîme-i câriyeden olmasıyla müstasniin akd-i istısnâyı fesihte muhayyer olması nice mesâlih-i cesîmeyi ihlâl edeceğinden ve istısnâ hususu, hilâf-1 kıyas olarak örf-i nâsa mebni istihsânen meşru olan seleme makîs ve örfe müstenid bir keyfiyet olduğundan maslahat-1 asra nazaran İmam Ebû Yûsuf kavlinin ihtiyarına lüzum görülerek 392. madde âna muvafık olarak yazılmıştır”.

\section{Mezhebin Mercûh ve Metrûk Görüşleriyle Fetvâ Vermek}

Bu meseleyi iki maddede ele alacağız:

\section{a. Mercûh görüşle fetvâ}

Normal şartlarda mezhepteki râcih yani kuvvetli görüş öncelenmeli; mercûh yani zayıf görüşle fetvâ vermemeye özen göstermelidir. Kaynaklardaki bazı nakillere göre Mâlikîlerden Bâcî (ö. 474/1081) ve Karâfî (ö. 684/1285), Şâfiîlerden İbnü’s-Salâh (ö. 643/1245) ve İbn Hacer (ö. 852/1449), Hanbelîlerden İbn Kudâme (ö. 620/1223), Hanefîlerden Kâsım b. Kutluboğa (ö. 879/1474), Zâhirîlerden İbn Hazm (ö. 456/1064) gibi âlimler, râcihin karşıtı olan mercûh ile fetvâ vermenin icmaya aykırı olacağını söylemişlerdir. Onlara göre, bir tercih sebebine bağlı olarak herhangi bir tercihte bulunmadan rastgele bir görüşe bağlanmak ve dilediği ictihad ile amel etmek, hevaya uymaktır, bir tür cehalettir ve icmaya aykırılıktır. ${ }^{67}$

Fakat genel tavır böyle olmakla birlikte, fevkalade durumlarda ve zorunluluk hallerinde mercûh/zayıf görüşle amel ve fetvânın mümkün olabileceği de birçok âlim tarafından dile getirilmiştir. Mesela Ebû Yûsuf'un, ihtilam esnasında erkeklik uzvunun ucunu sıkarak meninin $o$ anda dışarı çıkmasına engel olunması halinde gusül gerekmeyeceği ictihadı mercûhtur. Fakat bir başkasının evinde misafir bulunan ya da yolculukta olan kimsenin gusletme zorluğu varsa, öyle bir durumda zarurete bağlı olarak bu görüşle amel etmesine cevaz verilmiştir. Aynı şekilde Merğînânînin (ö. 593/1197) yaradan azar azar ama sürekli çıkan sıvının, bir bezle silinse bile abdesti bozmayacağı yönündeki ictihadı, mezhebte mercûh sayılmıştır. Fakat özür sahibi kimselere, durumlarını kolaylaştırmak için bu ictihadla amele cevaz verilmiştir. Nitekim İbn Âbidîn, geçirdiği bir rahatsızlık sırasında kendisinin de Merğînânînin söz konusu ictihadıyla amel ettiğini bildirmiş̧ir. ${ }^{68}$

Hatta bazı Hanefî kaynakları, Fahrulislam Pezdevînin (ö. 482/1089), yukarıda da geçtiği üzere, zor durumlarda ve kolaylaştırma amacıyla olmak kaydıyla zayıf görüşlerle hem amel hem de fetvâyı daha uygun bulduğunu naklederler. ${ }^{69}$ Öyleyse, standart hüküm haline getirmemek ve genel bir fetvâ formunda algılanmasına kapı açmamak gibi duyarlılıklara dikkat ederek, ciddi boyutlardaki zorluk ve ihtiyacın râcih görüşle giderilemediği sıkıntılı durumlarda, mercûh görüşle

67 Karâfî, el-İhkâm, s. 77, 93; Şâtıbî, el-Muvâfakât, IV, 95-96, 101; İbn Âbidîn, “Ukûdü Resmi'l-müftî”, I, 10-11, 48-49; bk.

İbn Hamdân, Sifatül-fetvâ, s. 39-41.

68 İbn Âbidîn, "Ukûdü Resmi'l-müftî", I, 50; a.mlf, Reddü'l-muhtâr, I, 51.

69 bk. İbn Âbidîn, "Ukûdü Resmi'l-müftî”, I, 35, 49; a.mlf, Reddü'l-muhtâr, I, 51; a.mlf., "Neşru'l-arf”, II, 125. 
"kişiye özel” fetvâ verilebilecektir.

Ebû Hanîfe'nin bizzat kendi hayatında cereyan eden bir hadise bu yaklaşımı teyit etmektedir. Ebû Hanîfe, kalın bile olsalar deri ile kaplı olmayan çoraplar üzerine meshetmeyi uygun bulmazken, öğrencileri Ebû Yûsuf ve Muhammed Şeybânî sıkı dokunmuş kalın çoraplara meshi caiz saymışlardır. Ömrünün sonlarında yakalandığı bir hastalık sırasında Ebû Hanîfe, aradığı şartları taşımayan çorapları üzerine meshetmiş ve o sırada ziyaretine gelenlere "İnsanları engellediğim bir işi bugün kendim yaptım” demiştir. ${ }^{70}$

Benzer bir durum hâkimin mahkemede mercûh görüşe göre hüküm tesisinde de söz konusudur. Esas ilke, davayı râcih görüşe göre sonuçlandırmaktır. Fakat ehliyetli ve âlim bir hâkim, mercûh görüşü de bazı gerekçelere bağlı olarak gündeme alabilecektir. Şeyhulislâm Ebussuûd Efendi'nin (ö. 982/1574) şu fetvâları hem konuyla ilgili geleneksel tavrı hem de mercûh görüşün hangi gerekçeyle yargılamada esas olabileceğini izah etmektedir:

"Mes'ele: Esahh-1 akvâl ile amel eylesün deyu berâtında mukayyed olan Zeyd-i kâdî, kavl-i zaîf ile amel eylese hükmü nâfiz olur mu?

el-Cevâb: Gayet zaîf olicak, olmaz."71

"Mes'ele: Zeyd-i kâdî bir kavl-i mercûhun delilinde kuvvet fehm idüp kavl-i mezbûr ile hükm eylese şer’an hükmü nâfiz olur mu?

el-Cevâb: Kâdî edille ve ahkâmın tahsîline (tefâsîline) vâkıf ulemâ-yı izâmdan olmayıcak, olmaz."72

Mercûh görüşün kanunlaştırılmasını, mercûh görüşle fetvâ vermekten ayrı mütalaa etmek gerekir. Kamu otoritesi, bireyin ve toplumun maslahatını düşünerek mercûh görüşleri gerektiğinde kanun maddesi haline getirip herkese şâmil kılabilir. Daha önce geçtiği üzere “İmamu’lmüslimin hazretleri, herhangi kavil ile amel olunmak üzere emreder ise mûcebince amel olunur". Bu durumda mercûh görüş artık bağlayıcı görüş haline gelir. ${ }^{73}$ Mesela Mecelle, nakit muhayyerliğiyle ilgili 313. maddeyi İmam Muhammed’in mezhepte tek kaldığı görüşe, havâleyle ilgili 692. maddeyi İmam Züfer’in görüşüne göre düzenlemiştir.

Mısır’da 1920 yılında yürürlüğe giren 25 nolu kanun, başlangıç cümlelerinde Hanefî mezhebindeki râcih ictihadın esas alındığını, bununla birlikte bazı meselelerin zamanın maslahatı gereği mezhebin mercûh görüşüne göre kanunlaştırıldığını beyan etmiştir. Bunlardan biri de İmam Muhammed'in eşteki ayıp, beden kusuru ve hastalık sebebiyle tefrîk imkânını genişleten görüşüdür. ${ }^{74}$

\section{b. Metrûk görüșle fetvâ}

70 Tirmizî, “Tahâret”, 74; Kâsânî, Bedâiu’s-sanâi, Beyrut 1986, I, 10.

71 Ebussuûd, Ma'rûzât, s. 130, 247; Düzenli, Şeyhulislâm Ebussuûd Efendi ve Fetvâları, s. 370.

72 Ebussuûd, Ma’rûzât, s. 130, 249; Düzenli, Şeyhulislâm Ebussuûd Efendi ve Fetvâları, s. 370; bk. Kaşıçıı, İslâm ve Osmanlı Hukukunda Mecelle, s. 312. Yani kadı, eğer delilleri ve istinbat yollarını iyice kavramış olan bir âlim ise mercûh/ zayıf görüşle hüküm verebilecektir.

73 Küçük Hamdi (Elmalılı), "Makâle-i Mühimme”, s. 403-404

74 Başka örneklerle birlikte bk. Merâğ 1 , el-İctihad fi'l-İslâm, s. 53-54. 
Sâbit ve sarih naslara aykırı olan ve bu sebeple literatürde "metrûk" veya "mehcûr" olarak nitelenen görüşlerle fetvâ vermekten de sakınmalıdır. Gerek dayanaktan yoksunluğu ve gerekse genel İslamî anlayışla uyumlu olmadığı için ümmet tarafından benimsenmeyen bu tür reyler, şâz olarak da nitelenmiştir. ${ }^{75}$

$\mathrm{Bu}$ ilkenin temellendirilmesi bağlamında şu kural hatırlanabilir: "Mevrid-i nasta ictihada mesâğ yoktur". Sübûtu ve delâleti kat'î olan bir nas söz konusu olduğunda mesele zaten çözümlenmiş demektir. Delâleti zannî olduğunda ise gerektiğinde o nas üzerinde beyan ictihadı yapılabilir ki, bu durumda da yine nassa bağlı bir hüküm elde edilmiş olur.

Bazen de bir hadis rivayeti bulunur, fakat o konudaki daha sahih ve kabule şayan başka rivayetler dolayısıyla kendisiyle amel edilmemiş olabilir. İşte bu durumlardan birisi sebebiyle ümmet tarafından terkedilmiş bulunan rivayet ve görüşlere dayanarak fetvâ vermek doğru olmayacaktır. Tirmizînin (ö. 279/892) şu sözleri bu yaklaşıma güzel bir örnektir:

"İkisi hariç, benim şu kitabımda bulunan hadislerin hepsiyle ehl-i ilim amel etmiştir. Amel edilmeyen o iki rivayet ise şunlardır:

1. “Nebi (s.a) korku (savaş), yolculuk ve yağmur gibi herhangi bir sebep yokken öğle namazı ile ikindi namazını ve akşam namazı ile yatsı namazını Medine’de cem etti."

2. "Bir kişi ilk kez içki içtiğinde ona celde cezasını uygulayın. Bu suçu dördüncü kez tekrarladığında ise onu öldürün.”76

Aynı şekilde İbn Abbas’a (r.a.) nisbet edilen müt’a nikâhı ile fazlalık ribasının (ribe’l-fadl) meşruiyeti görüşü, Saîd b. el-Müseyyeb’e (ö. 94/713) izafe edilen üç talakla boşandıktan sonra başka birisiyle evlenen bir kadının, bu yeni evliliğinde zifafa girmese bile eski kocasına helâl olacağı ictihadı, Atâ b. Ebî Rabâh’n (ö. 114/732) ehl-i kitaptan hanımlarla evlenme meşruiyetinin neshedildiği kanaati de metrûk/şâzz görüşlere örnektir. ${ }^{77}$ Zira bu görüşler hem Hz. Peygamber'in açık beyanlarıyla çelişmekte, hem de icmaya aykırı düşmektedir.

Burada İmam Evzâînin (ö. 157/774) biraz ağır bir üslupla “ulemanın şâz görüşlerini (nevâdir) benimseyen kimse İslam dairesinin dışına çıkar"78 şeklindeki ikazına dayanarak kaydedelim ki, müsteftînin akraba, komşu ve arkadaş gibi, halini daha yakından bildiği birisi olması, müftîye, mevcut görüşler arasından ona en uygununu fetvâ olarak verme hakkı doğurmaz. Mâlikî çevrelerde bu yönde bir tutum olduğuna işaret eden İbnü’s-Salâh (ö.643/1245) ve İbn Hamdân (ö. 695/1295), böyle bir davranışın haram olacağında ulemânın ittifak ettiğini söylerler. ${ }^{79}$ Mâlikî âlim Ebu'l-Velîd el-Bâcînin de (ö. 474/1081) icmaya aykırı bularak eleştirdiği bu yanlış yaklaşım, sonraki Mâlikîler arasında daha makul bir çizgiye çekilmiştir. Nitekim Desûkî (ö. 1230/1814) "Müftî için dostuna, onun gerçekten zaruret içinde olduğunu anladiğı zaman meşhur olmayan görüşle fetvâ vermesi caizdir; çünkü dostun hali gizli değildir" ${ }^{\prime 0}$ diyerek, söz konusu tercih imkânının, yu-

75 Ayrıntılar için bk. Mübârekî, Ahmed b. Ali, el-Kavlü’ş-şâz ve eseruh fi’l-fütyâ, Riyad 1431, s. 63 vd.

76 Tirmizî, İlelü't-Tirmizî (el-Câmiu's-sahîh ile birlikte, thk. A.M. Şâkir-M.F. Abdülbaki- İ.U.Avd) Kahire 1962 , s. 1.

77 bk. Şevkânî, İşâdü'l-fuhûl, s. 1107-1108.

78 Beyhakî, es-Sünenü’l-kübrâ, Beyrut 2003, X, 356, H.no: 20918; Şevkânî, age., s. 1108.

79 İbnü's-Salâh, Edebü'l-müftî ve'l-müsteftî, s. 63; İbn Hamdân, Sifatü'l-fetvâ, s. 41.

80 Desûkî, Hâşiyetü'd-Desûkî aleş-Şerhi'l-kebîr, Kahire ts. (Dâru İhyâi'l-Kütübi'l-Arabiyye), IV, 130; ayrıca bk. Karadâvî, 
karıda geçtiği üzere, gerçekten baş göstermiş zaruret halleriyle sınırlı olduğuna vurgu yapmıştır.

Bu ilke bağlamında avâma/sıradan kişilere görüşlerden ağır olanla, yöneticilere ve havâssa hafif olanı ile fetvâ vermenin yanlışlı̆̆ına da işaret edilmelidir. Âlimler böyle davranmayı fısk, dine ihanet ve müslümanlarla oyun oynamak olarak nitelendirmişlerdir. ${ }^{81}$

\section{Fetvâda Telfîk}

Müctehid müftî, değişik unsurları ya da parçaları olan bir meselenin her bir boyutunu bağımsız olarak ele almalı ve benimsediği kaynak-yöntem teorisine göre o parçalara ilişkin hükmü tesbit etmelidir. Mesela başı meshetmek, organları yıkarken ovmak gibi eylemler abdest bütünü içinde; küçükleri evlendirmek, veliyi gerekli görmek, şahitlik gibi eylemler nikâh bütünü içinde anlamlı olsa da, bütünün parçaları bağımsız kimliğe sahip olup bağımsız birer şer’î hükme bağlanırlar.

Parçaların her birine ictihad, tahrîc ya da tercih yoluyla bağladığımız hükümlerin farklı mezheplerce benimsenmiş olması, o meselede telfîk yapıldığı anlamına gelmez. Olsa olsa ictihad ya da tercihin onlarla bir noktada buluşması anlamına gelir. Zira bir fer'î meselede birden fazla müctehidin görüşünü birleştirmek demek olan telfîk, amelde bahis konusu olur ve dolayısıyla müftînin değil mukallidin sorunudur. Daha açık bir ifadeyle, mukallid kişi, parçaları ve unsurları olan bir ameli, sormadan ve araştırmadan aklına geldiği gibi parçanın veya unsurun birisini bir mezhebe, diğerini başka bir mezhebe, ötekini de üçüncü bir mezhebe göre eda ederse telfîk yapmış olur. Mesela abdestte niyet konusunda Hanefî, tertip (muvâlât) konusunda Şâfiî, yıkanan uzuvları ovma (delk, tedlîk) konusunda Mâlikî mezhebini uygulamak gibi.

Oysa iftâ eylemi aynı zamanda bir ictihad olduğuna göre bunda telfîk diye bir sorundan söz edilemez. ${ }^{82}$ Müctehid ya da tercih ehli olan bir müftî, bu parça ya da unsurların her birini müstakil olarak değerlendirir ve birbirinden bağımsız olarak hükme bağlar. Dolayısıyla fetvâ veren kişi ya da kurum her bir parçayı bağımsız bir incelemeyle hükme bağlayınca kimilerince eleştirilen telfîk işleminden de uzak kalmış olur. Bilindiği üzere eleştirilen telfîk, taklitte telfîktır ve bu da "belli bir meselede birden fazla ictihadî görüşü bir arada sayılabilecek şekilde birleştirerek, bu müctehidlerden hiçbirisinin kabul etmeyeceği mürekkep bir durumun ortaya çıkmasıdır." ${ }^{3}$

Müslümanların ihtiyaç duyduğu hukuk düzeninin mutlaka İslâm dairesi içinde kalınarak kurulması gerektiğine işaret eden Elmalılı Hamdi Yazır’ın (ö. 1942) bunu somutlaştırmak üzere yaptığı açıklamalar da bu yöndedir. Kanunlar hazırlanırken öncelikle Hanefî mezhebinin esas alınmasını, bunun yeterli olmadığı durumlarda diğer mezheplerden istifade edilmesini, meselenin bu yolla da çözülememesi halinde Avrupa kanunlarından iktibasta bulunmak yerine istinbat kuralları muvacehesinde yeni ictihadlar yapılmasını öneren Elmalılı, bu yöntemin mezheplerin telfîkı olarak anlaşılmaması gerektiğini, zira telfîkın tek bir meselede iki mezhebe göre amel et-

İslâm Hukuku, s. 107; Dahîl, el-Fetvâ, s. 313

81 Karâfî, el-İhkâm, s. 250.

82 bk. Kâsımî, el-Fetvâ fi'l-İslâm, s. 170; Karaman, İslâm Hukukunda İctihad, s. 222-224. Senhûrî kendisinin geliștirdiği bir "ictihadda telfîk" kavramından bahseder; fakat yaptığı izah, daha ziyade fikıh usûlündeki "üçüncü görüşün imkânı/imkânsızlığı” meselesi çerçevesindedir. bk. Senhûrî, "Mezheplerin Hükümleri Arasında Telfik”, Karaman, Hayreddin, İctihad Taklid ve Telfik Üzerine Dört Risale, İstanbul 1982, s. 236-248.

83 Karaman, İslâm Hukukunda İctihad, s. 220 vd. 
mek demek olduğunu belirtir. ${ }^{84}$

Zikrettiğimiz gerekçelere bağlı olarak bizim burada onayladığımız üzere, müftînin meseleyi etraflıca araştırma ve delilleri inceleme sonucunda görüşleri birleştirmesi yoluyla daha önce hiçbir müctehidin söylemediği bir sonuca ulaşması, bazı âlimlerce icmaya aykırılık ve dinî hükümlerde lâübâlilik iddiasıyla kabul edilmemiştir. ${ }^{85}$ Mezhep disiplinini koruma kaygısından kaynaklanan bu itirazların son tahlilde yeterince güçlü olmadığı söylenebilir. Zira icmaya aykırılık iddiası, usûl-i fıkıhta teorisi belirlenen “icma” kavramı dikkate alındığında temelsiz kalmaktadır. Dinî hükümleri oyuncak haline getirme iddiası da, müftînin müctehid ya da tercih ehli bir fakih olması, onun da belli ilmî-akademik yetki ve sorumluluklarının bulunması niteliğiyle bağdaşmamaktadır. Kaldı ki, burada daha baştan sû-i zanda bulunarak bir niyet okuması yapmak da müslümanlık ilkeleri açısından doğru görünmemektedir.

\section{Mezhep Görüşlerinin Hiyerarşisi}

Mezhep esaslı iftâ işleminin ustalık isteyen bir yönü de "alâmâtü’l-iftâ" denen ve mezhepte fetvâya esas olan görüşlerin hiyerarşisini gösteren ifadeleri birbirinden ayırt edebilmektir. İki büyük mezhep özelinde görüş hiyerarşisini yakın plana alalım:

\section{a. Hanefîlerdeki hiyerarşi ${ }^{86}$ :}

1. "Aleyhi amelü’l-ümmet” ile sevkedilen fetvâ, en kuvvetlisidir. Zira o hüküm üzerinde görüş birliği (icma) bulunduğunu bildirmektedir.

2. İçinde "fetvâ" kelimesi bulunan ifadeler, bulunmayanlara göre daha kuvvetlidir. Mesela "bihî yüftâ", "aleyhi'l-fetvâ" gibi alametlerle zikredilenler "esah", "sahîh” ve "eşbeh" olarak nitelenenlerden daha kuvvetlidir. Zira her uygun olan görüşle fetvâ verilmemiş olabilir ya da zarurete, örfe, ihtiyaca binaen zamanla fetvâ değişmiş olabilir. Diğer taraftan "fetvâ" kelimeli alametle verilen hüküm, hem sahih olması hem de tercih edilmiş olması gibi iki içeriğe birden sahiptir.

3. İçinde "fetvâ" kelimesi bulunan alametlerden hasr ifade edenler etmeyenlerden önce gelir. Mesela "bihî yüftâ" ya da "aleyhi'l-fetvâ" ile nakledilen, "yüftâ bihî" veya "el-fetvâ aleyh" diye nakledilenden kuvvetlidir. Zira öncekilerde "iște bununla, buna göre" vurgusu fetvâ kelimesinin önünde zikredilerek hasr yapılmaktadır.

4. "Esah" "sahih"ten; "ahvat" "ihtiyat"tan daha önce gelir.

5. Bir konuda ikisi de aynı alametlerle nakledilen iki ayrı görüş varsa, müftî, görüşlerin sahiplerinin mezhepteki derecesine göre tercihte bulunur. Aynı derecedeler ise bir gerekçeye (muraccıh) bağlı olarak dilediğini seçip onunla fetvâ verebilir. Delilin açıklığı veya kuvveti, tercih sebeplerinin başında gelir.

6. Aynı derecedeki alametlerle nakledilen fetvâlar arasında bir gerekçeye bağlı olarak tercihte

84 Küçük Hamdi, “Makâle-i Mühimme”, s. 403-404; bk. Yavuz, Yûsuf Şevki, "Elmalılı Muhammed Hamdi”, DİA, XI, 59. 85 Karaman, age., s. 223-229.

86 İbn Âbidîn, “Ukûdü resmi'l-müftî”, I, 38-40; a.mlf, Reddü'l-muhtâr, I, 49-50. Hanefî mezhebinde râcih görüşü belirleme ölçütleri konusunda bk. Nakîb, el-Mezhebü'l-Hanefî̀, I, 243-278. 
bulunulamıyorsa, mezhebin temel metinlerinde nakledilen görüşler, diğer eserlerde nakledilenlere öncelenir. Çünkü metinler, mezhebin temel görüşlerini nakletmek için yazılmış kitaplardır. Bir başka ifadeyle metinler şerhlere, şerhler de fetvâ ve vâkıat kitaplarına tercih edilir. En muteber metinlerin başında ise Hâkim Şehîd el-Mervezînin (ö. 334/945) el-Muhtasaru'l-Kâfî̀, Kudûrînin (ö. 428/1037) Muhtasaru'l-Kudûrî, Merğînânînin (ö. 593/1197) Bidâyetü’l-Mübtedî, Mevsilînnin (ö. 683/1284) el-Muhtâr, Sadruşşerîa es-Sânînin (ö. 747/1346) en-Nükâye, Tâcüşşerîa el-Mahbûbînin (ö. 673/1274) el-Vikâye, Ebu'l-Berakât en-Nesefînin (ö.710/1310) Kenzü’dDekâık ile İbrahim el-Halebînin (ö.956/1594) Mültekâ’l-Ebhur isimli eserleri gelmektedir. ${ }^{87}$

7. Metinler aracılığıyla bir tercih yapılamıyorsa, meşâyıhın yani mezhebin önde gelen fakihlerinin çoğunluğunun benimsediği görüş tercih edilir.

Bunlardan sonra eğer "sahih, esah, ahvat, akrab” gibi bir tashih, tercih ve öncelik sıralaması yapılmamışsa:

a. İmam Ebû Hanîfe’nin görüşü diğerlerine öncelenir.

b. Ebû Hanîfe'den iki kavil (kavleyn) nakledilmişse, ikisi de ona ait sayılır ve hangisinin son görüşü olduğu tesbit edilemiyorsa delil bakımından en kuvvetli olanı alınır. Bu aşamada bir tercih imkânı bulunamamışsa ihtiyata en uygun olup kalbin meylettiği kavil ile fetvâ verilir. Eğer onun görüşünün ne olduğu konusunda iki rivayet (rivâyeteyn) varsa bunlardan birisi ona ait kabul edilir. Zira rivayet bir nakilden ibarettir ve onu nakledenlerin yanılması da ihtimal dâhilindedir. Bu durumda, delilin kuvveti ve kalbin meyli yanında, önde gelen fakihlerin (meşâyıh) rivayetlerden hangisini benimsemiş olduğu da tercihte belirleyici olacaktır.

c. Ebû Hanîfe ile birlikte iki büyük öğrencisinden biri aynı görüşte birleşmişlerse o görüş tercih edilir. Ebû Hanîfe ile Ebû Yusuf birlikteliği “şeyhayn”, Ebû Hanîfe ile Muhammed eş-Şeybânî birlikteliği “tarafeyn”, Ebû Yusuf ile Muhammed birlikteliği “imameyn” olarak nitelendirilir.

d. İmam-1 Âzam bir görüşte, iki meşhur öğrencisi beraberce başka bir görüşte iseler, müftî, müctehid derecesine yakın bir yetişmişliğe yani tahric ve tercih ehliyetine sahipse delilleri inceleyerek dilediğini tercih edebilir. Zaruret ve baskın ihtiyaç gibi gerekçeler de bu tercihi yönlendirebilir.

e. Ebû Hanîfe ile meşhur iki öğrencisi arasındaki ihtilaf, zamanın veya örfün değişmesinden kaynaklanmış ise, iki öğrencisinin görüşü tercih edilir.

f. Eğer kurucu üç imam arasında ihtilaf varsa, tekrar edilegelen meşhur sınıflamaya göre ibadet konularında Ebû Hanîfe, yargılama hukuku alanında Ebû Yûsuf, miras hukukunu ilgilendiren bazı konularda da Muhammed Şeybânînin görüşleri öncelenir.

g. Zâhirurrivâye olan hüküm böyle olmayana yani nâdirurrivâyeye öncelenir.

h. Meseleyle ilgili olarak Zâhirurrivâye bir hüküm yoksa, Hanefî usûlüyle uyumlu olması şartıyla nâdirurrivâye olan hüküm alınır.

87 Hanefî eserlerinin muteberlik ölçütleri konusunda bk. İbn Âbidîn, “Ukûdü Resmi'l-müftî”, I, 13, 16-21; Bilmen, Hukuk-ı İslâmiyye, VIII, 260; Nakîb, el-Mezhebü’l-Hanefî̀, I, 219-243. 
1. İstihsana dayanan çözüm kıyasa dayanana genellikle tercih edilir.

i. İçinde yaşanılan zamanın gereklerine ve örfüne uygun olan, diğerine öncelenir.

j. İnsanların veya toplumun yararına olan ve onların işlerini kolaylaştıran, böyle olmayana tercih edilir.

k. Mezhebin önderlerinden herhangi bir naklin olmadığı konularda, sonrakilerin ittifakı varsa onunla amel edilir. Böyle bir fikir birliği yoksa müftî, kendisine en doğru gelen görüşü benimser. $^{88}$

\section{b. Şâfiîlerdeki hiyerarşi}

Sıralamaya geçmeden önce hem Şâfiî eserlerini daha iyi anlayabilmek hem de söz konusu hiyerarşiyi takip edebilmek bakımından mezhebe özgü bazı terimleri hatırlamak gerekmektedir:

Kavl (çoğulu: akvâl): Mezhebin kurucu imamı Şafiî̉nin görüşü/görüşleridir. Şâfiînnin Irak dönemindeki görüsslerine el-kavlü'l-kadîm, Mısır dönemindeki görüşlerine el-kavlül-cedîd denmiştir.

Vech (çoğulu: vücûh-evcüh): Kendilerine ashâbu'l-vücûh denen yetkin Şafiî fakihlerin, İmam Şâfiî̀den sonra mezhebin yerleşik usûlüne göre tahric edip ürettikleri hükümlerdir.

Tarîk (çoğulu: turuk): Vech anlamında kullananlar varsa da daha çok, İmam Şâfiî̀den veya ashâbu'l-vücûhtan bir konuda birden fazla hüküm rivayeti gelmiş olmasını ve bu gelenlerin de onlara âidiyet problemi taşımasını ifade eder. Kısacası, ashabu'l-vücûhun mezhep görüşünü nakildeki ihtilafları anlamına gelir. Mesela aynı mesele hakkında bir âlim "Bu konuda iki kavil vardır" derken bir başka âlimin "Bu konuda tek bir kavil vardır" demesi veya birisi "Bu konuda iki vecih vardır" derken diğerinin "Tek vecih vardır" demesi ya da "Konunun değişik ayrıntılarına göre farklı görüşler vardır (fîhi tafsîl)" tesbitine karşıllk "Bu meselede birbirine zıt iki görüş vardır (fîhi hılâf mutlak)" denmesi gibi. ${ }^{89}$

Şeyh: Mutlak olarak kullanıldığında Nevevî (ö. 676/1277) kastedilir.

Şeyhân/Şeyhayn: Râfiî (ö. 623/1226) ve Nevevî kastedilir. ${ }^{90}$

Şüyûh: Râfiî, Nevevî ve Sübkî (ö. 756/1355) kastedilir.

Esah: Vecihlerden en isabetli olanıdır.

Evceh: Vecihlerden esah olanıdır.

Azhar: Mevcut iki veya daha fazla kavil, vech veya tarîkden daha güçlü ve tercihe layık olanıdır. Mu’temed diye de isimlendirilir. Bu durumda diğerleri zâhir olarak nitelenir.

Şafiî mezhebindeki hüküm hiyerarşisi, bir başka deyimle fetvâya esas olan görüş ve hükümler şöyle sıralanmıştır:

88 Kâdîhân, el-Fetâvâll-Hâniyye, I, 3; İbn Âbidîn, “Ukûdü resmi'l-müftî”, I, 22, 26-29, 35.

89 Nevevî, el-Mecmû, I, 107-108.

90 Ebû Zehra, Şâfî̀: Hayâtüh ve asruh, Kahire 1948, s. 350; Aybakan, Bilal, İmam Şâfî̀ ve Fıkıh Düşüncesinin Mezhepleşmesi, İstanbul 2007, s. 206-209. 
1. Mezhebin kurucusu Şâfiîdden tek kavl/görüş nakledilmişse bu esas alınır.

2. Birden fazla kavl/görüş gelmişse, prensip olarak kavl-i cedîdi öncelenir. Kural öyle olmakla birlikte, mezhep müctehidleri yirmi kadar meselede kavl-i kadîm ile fetvâ vermiştir. ${ }^{11}$

3. İmam Şâfiî̀den yapılan aynı nitelikteki kaviller arasında farklılık olursa Müzenî (ö. 264/878) ve Rebî b. Süleyman el-Murâdînin (ö. 270/884) nakilleri daha güvenilir sayılır.92

4. Aynı konuda birden fazla kavl-i cedîd nakledilmişse, ashâbu'l-vücûhun tercihi dikkate al1nır. Bu meyanda mezhebin râcih görüşünün belirlenmesinde şeyhaynin yani Râfiî ve Nevevînnin tercihlerinin ayrı bir değeri vardır. Her ikisinin ittifak ettiği görüş, mezhebin en mutemet görüşüdür. İhtilaf etmişlerse Nevevînin görüşü öne çıkar. Nevevînin görüşü ya da tercihi yoksa, mezhep ileri gelenlerinin mutemet gördükleri görüşle fetvâ verilir.

Bütün bu aşamalar sırasında bakılacak kaynak eserler de şöyle sıralanır:

Önce Nevevînin eserlerine bakılır. Bunlar da kendi içinde öncelik ve önem bakımından şöyle siralanir:

et-Tahkîk: el-Mecmû̉dan faydalanarak hazırladığg yarım kalmış bir eserdir.

el-Mecmû: Şîrâzînin (ö. 476/1083) el-Mühezzeb’i üzerine yaptı̆̆ı yarım kalmış bir şerhtir.

et-Tenkîh: Gazzâlînin (ö. 505/1111) el-Vasît isimli kitabının tamamlanmamış bir şerhidir.

Ravdatü'-Tâlibîn: Râfiînnin (ö. 623/1226) Gazzâlînin el-Vecîz'i üzerine yazdı̆̆g Fethu'l-Azîz (eş-Şerhu'l-Kebîr) isimli şerhinin muhtasarıdır.

Minhâcü't-Tâlibîn: Râfiînin el-Muharrer isimli eserinin özetidir.

el-Minhâc fî Şerhi Sahîhi Müslim: Müslim'in (ö. 261/875) el-Câmiu’s-Sahîh'inin şerhidir.93

Bunlardan sonra Misırlı Şâfiîler Şemseddin er-Remlînin (ö. 1004/1596) Nihâyetü’lMuhtâc'indaki görüşleri; Şam, Hicaz ve Yemenli Şâfiîler ise İbn Hacer el-Heytemînin (ö. 974/1567) özellikle Tuhfetü’l-Muhtâc isimli eserindeki görüşleri mutemet saymışlardır. Bu iki eserde bulunmayan konulara gelince bunlarda fetvânın, şu eserlerdeki görüşlere göre verileceği benimsenmiştir:

Zekeriya el-Ensârî (ö. 926/1520), Şerhu'l-Behce ile Menhecü't-Tâlib.

Hatîb eş-Şirbînî (ö. 977/1570), Muğni’l-Muhtâc.

Bunlardan sonra sıra, meşhur hâşiyelere gelir. Onlar arasında da özellikle Hâşiyetü’z-Ziyâdî, Hâşiyetü İbn Kâsım ve Hâşiyetü’ş-Şebrâmellisî fetvâ kaynağı olarak temayüz etmiştir.

91 Tercih edilen kavl-i kadîmin bir listesi için bk. Nevevî, el-Mecmû, I, 108-109. Büceyrimî, Hâşiyetü’l-Büceyrimî ale’lHatîb, Misır 1951, I, 45-48. Bu konuda ayrıca bk. Candan, Abdurrahman, Imam Şâfî̀nin Kavl-i Kadim ve Kavl-i Cedidi (yüksek lisans tezi, 1998), Yüzüncü Yll Üniversitesi, Van.

92 İbnü's-Salâh, Edebü'l-müftî ve’l-müsteftî, s. 64-65; Nevevî, el-Mecmû, I, 115; Atar, “Fetvâ”, DİA, XII, 492.

93 Bir örnek üzerinde uygularsak, kuşluk namazının en çok kaç rekât olacağ1, el-Mecmû̉da (III, 529) sekiz, Şerhu Müslim'de (II, 117) on iki olarak kaydedilmiştir. el-Mecmû daha önde olduğu içindir ki, sonrakiler sekiz rekat görüşünü benimsemişlerdir. 


\section{Fetvânın Verileceği Mezhep Kaynaklarını Belirlemek}

Müftî, fetvâda esas alacağı mezhep kaynaklarını seçerken onların değerine ve hiyerarşisine dikkat etmelidir. Daha açık bir ifadeyle öncelikle mütekaddimûn sayılan fakihlerin eserleri tercih edilmelidir. Zira sonraki kitaplarda bazı yanlış yazımlar ve anlamalar bulunabilmektedir. Konunun bu eserlerde ele alınış tarzı kavrandıktan sonra mezhep içinde değişim olup olmadığını görmek için sonraki eserlere bakılabilir.

Bu kuralın ne kadar önemli olduğunu görmek için İbn Âbidîn’in verdiği şu örneklere ${ }^{94}$ göz atalım: Hanefî mezhebinin klasik kaynaklarında yer alan Kurân-ı Kerîm’in öğretilmesi karşılığında ücret alınabileceği şeklindeki ictihad, sonraki bazı fakihlerce yanlış yorumlanarak, ücretle Kurân okutulmasına ve bunun karşllığında alınan paranın helâl olduğuna fetvâ verilmiştir. Daha sonra da bu yanlış tespit, sanki mezhebin müftâ_bih görüşüymüş gibi kitaplarda tekrar edilegelmiştir. Hatta daha da ileri gidilerek, tâat-ibadet cinsinden fiillerin ücretle yaptırılabileceği bile söylenmiştir. Hal böyle olunca mesela hac ibadetinin ücretle tutulan başka birisi üzerinden ifâ edilebileceği dile getirilmiştir ki, bu bütünüyle yanlış bir yaklaşımdır. ${ }^{95}$

el-Fetâvâll-Bezzâziyye'de Hz. Peygamber’e hakaret edip söven kimsenin, Hanefî mezhebine göre tövbesinin kabul edilmeyeceği ve ölümle cezalandırılacağı kesin bir dille ifade edilmiştir. Öyle ki bu yanlış nispet daha sonra İbnü’l-Hümâm (ö. 861/1457) ve Molla Hüsrev (ö. 885/1480) gibi fakihler tarafından da tekrar edilmiştir. Oysa mezhebin bu konudaki asıl görüşü, Ebû Yûsuf'un (ö. 182/798) el-Harâc’’ ile Tahâvînin (ö. 321/933) el-Muhtasar’ında zikredildiği üzere, suçlunun tövbesinin kabul edileceği ve ölüm cezasının düşeceği şeklindedir.

Aynı durumun diğer mezhepler için de söz konusu olabileceği unutulmamalıdır. Fetvâya esas olmak üzere mütekaddim âlimler tarafından tasnif edilen eserlerin tercih edilmesi gerektiğini söyleyen Karâfî (ö. 684/1285), sıhhat ve güvenilirlik şüphesi olabileceğinden yeni kitapların ve hâşiyelerin kaynak olarak kullanılmasını doğru bulmaz. ${ }^{96}$ İmamlığa liyakat sebepleri arasında imam adayının cinsel organı ve eşi ile ilgili kıstaslar, kızların mirasta erkek kardeşleriyle eşit oranda hisse almaları, hayızlı hanımların oruç tutabilecekleri, yatsı namazının mevsim farkı olmaksızın akşam namazından bir saat yirmi dakika sonra gireceği yönünde sonraki kitaplarda yer alan görüşler, bu duyarlılığın ne kadar gerekli ve yerinde olduğunu göstermektedir.

Bu bağlamda, mütebahhir olan bir hocadan okuyup, böylece fikıh müktesebatını müteselsilen öncekilerden almadan fetvâ vermenin doğru olmayacağı bir kere daha hatıllanmalıdır. Nitekim Nevevî (ö. 676/1277), Karâf̂́, İbn Hamdân (ö. 695/1295) ve İbn Hacer (ö. 852/1449), kendi başına ne kadar çok okursa okusun, rahle-i tedristen geçmeyen bir kişinin, kitaplardaki yanlışları fark edemeyeceği için fetvâ vermesinin caiz olmayacağını söylemişlerdir. ${ }^{97}$

Bu bağlamda, bir mezhebin hükmünün o mezhebin âlimlerinden ve kitaplarından nakledilmesi gerektiği hatırlanmalıdır. Bunu ifade için "Bir mezhep başka bir mezhepten nakledilmez" kuralı konmuştur.

94 Başka örneklerle birlikte bk. İbn Âbidîn, “Ukûdü Resmi'l-müftî”, I, 13-14.

95 İbn Âbidîn, örnek olarak verdiği söz konusu yanlışın Kudûrî şârihi Haddâd’dan (ö. 800/1398) kaynaklandığını söyler ki, bu, yanlış bir tespittir. Zira Haddâd, Kur'ân’n ücretle okutulması bir yana, öğretiminden bile ücret alınmasının caiz olmadığını açıkça yazar. Bk el-Cevheratü’n-neyyira, yy. 1322 (el-Matbaatü’l-Hayriyye), I, 269.

96 Karâfî, el-ïhkâm, s. 244-245; bk. Nevevî, el-Mecmû, I, 80-81.

97 Karâfî, age., s. 213, 244; İbn Hamdân, Sıfatü’l-fetvâ, s. 27; İbn Âbidîn, “Ukûdü Resmi'l-müftî”, I, s. 15-16. 


\section{Sonuç}

Fetvâ usûlünün en önemli ve fıkıh tarihi boyunca en tartışmalı boyutlarından biri olan fetvâmezhep ilişkisini konu edinen bu makale bize şu sonuçları vermiştir:

İftânın bir yönteme bağlı olarak gerçekleştirilmesi, isabetli hükme ulaşma ana hedefi yanında, toplumda fetvâ standardizasyonunu ve buna bağlı olarak hukuk emniyetini sağlamanın zorunlu bir gereğidir. Yöntem aynı zamanda fikhî ve mezhebî tutarlılığı da temin eder.

Fıkhî mezhepler, sivil birer gerçeklik olarak oluşmuş ve yayılmıştır. Dinî-hukukî hayatı tanzim eden fetvâ da daha çok hukukî istikrar endişesiyle bu mezheplerden birisine bağlı bir faaliyet olarak süre gelmiştir. Bu gerçek, ehliyetli ve dirayetli bir müftîyi, bağlı olduğu mezhebi her zaman ve durumda mutlaka iltizam etmek ve onun çerçevesinin dişına asla çıkmamak zorunda bırakmaz. Nitekim fakihlerin çoğunluğu amelî hayatın belli bir mezhebe göre sürdürülmesini caiz görmekle birlikte bunun mutlaka yerine getirilmesi gereken dinî bir gereklilik olmadığı kanaatindedir.

Fıkıh doktrinini usûlü, ilkeleri ve furûuyla kavrayabilen âlim bir müftî, metodolojik ve olgusal gerekliliklere bağlı olarak, kendi mezhebi içindeki görüşlerden birisini tercihle fetvâ verebileceği gibi, kendi mezhebi dışında bir başka görüşü benimseyip onunla da fetvâ verebilecektir. Aynı minvalde, metodolojik bir tavır ve ilkesel bir yaklaşım çerçevesinde fikıh mirasının bütününden faydalanmak mümkün olduğundan bilinen dört mezhebin dışına da çıkabilecektir.

Sabit ve sarih delillere aykırılığı sebebiyle "metrûk" veya "mehcûr" olarak nitelenen görüşlerle fetvâ vermek doğru bulunmamakla birlikte, fevkalade durumlarda ve zorunluluk hallerinde mercûh/zayıf görüşle amel ve fetvânın mümkün olabileceği anlaşılmaktadır.

Müctehid ya da tercih ehli olan bir müftî, bir meselenin parça ya da unsurlarının her birini müstakil olarak değerlendirip birbirinden bağımsız olarak hükme bağlayacağı için iftâda telfîk söz konusu olmaz.

Bütün bu konulardaki değerlendirmeler, takdir ve işlemler çok nitelikli bir ilmî donanım yanında derin bir tecrübeyi gerektirdiğinden ictihadın ferdîliğine mukabil, iftânın kurumsal düzeyde yürütülmesinin yerinde olacağı öngörülmüştür.

Konuyla ilgili bir ayrıntı olarak, müftînin, mezhepte fetvâya esas olan görüşlerin hiyerarşisini gösteren ifadelerin (alâmâtü’l-iftâ) ayırdında olmasının ve fetvâda esas alacağı mezhep kaynaklarını seçerken onların kıdem ve değerine göre bir belirlemede bulunmasının önemi ortaya çıkmıştır.

\section{Kaynaklar ${ }^{98}$}

Abdulkerim Zeydân, el-Mufassal fî ahkâmi'l-mer'e, Beyrut, 1993.

Aclûnî İsmail b. Muhammed, Keşfu'l-hafâ (nşr. A. Kalas), Kahire,

Aliyyü'1-Kârî b. Sultan, el-Masnû' fi ma'rifeti'l-mevdû' (thk. A. Ebu Gudde), Beyrut 1398/1978. Âmidî, Seyfeddin, el-İhkâm fî usîli'l-ahkâm, Beyrut ts.

98 Concordance’a uygun baskıları kullanıldığı için el-Kütübü't-Tis'a’ya burada yer verilmemiştir. 
Aşkar, Muhammed Süleyman, el-Fütyâ ve menâhicü'l-iftâ, Kuveyt 1976.

Atar, Fahrettin, "Fetvâ”, DİA, XII, 486-496.

Aybakan, Bilal, İmam Şâfî̀ ve Fıkıh Düşüncesinin Mezhepleşmesi, İstanbul 2007.

Beyhakî, Ebû Bekir, es-Sünenü’l-kübrâ, Beyrut 2003.

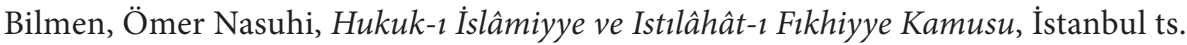

Bûtî, M. Saîd Ramadan, el-Lâmezhebiyye, Beyrut 1996.

Büceyrimî, Süleyman, Hâşiyetü’l-Büceyrimî ale’l-Hatîb, Misır 1951.

Candan, Abdurrahman, İmam Şâfî̀nin Kavl-i Kadim ve Kavl-i Cedidi, (yüksek lisans tezi, 1998), Yüzüncü Yıl Üniversitesi, Van.

Cassâs, Ebû Bekir, Ahkâmu'l-Kur'ân, Beyrut 1993.

Muhtasaru İhtilâfi'l-ulemâ, Beyrut 1417.

Dahîl, Abdurrahman b. Muhammed, el-Fetvâ ehemmiyyetühâ davâbıtuhâ âsâruhâ, Medîne 2007.

Debûsî, Ebû Zeyd, Takvîmü'l-edille fî usûli'l-fikh, (thk. H.M. Meys), Beyrut 2001.

Dehlevî, Şah Veliyyullah (ö. 1176/1762), Ikdü’l-cîd fî ahkâmi'l-ictihâd ve't-taklîd, Kahire 1978,

Desûkî, Ebû Abdillah, Hâşiyetü'd-Desûkî aleş-Şerhi'l-kebîr, Kahire ts.

Düzdağ, Ertuğrul, Şeyhülislam Ebussû̂d Efendi Fetvâları Işı̆̆ında 16. Asır Türk Hayatı, İstanbul 1983.

Düzenli, Pehlül, Şeyhulislâm Ebussuûd Efendi ve Fetvâları, İstanbul 2012.

Ebû Yûsuf, Yakub, Kitâbü'l-Harâc, Kahire 1382.

Ebû Zehra, Muhammed, İslâmda İtikadî Siyasî ve Fıkhî Mezhepler Tarihi (çev. S. Kaya), İstanbul ts. Mâlik, Kahire 1978.

Şâfî̀, Kahire 1948.

Ebussuûd Efendi, Ma'rûzât, (haz. Pehlül Düzenli), İstanbul 2013.

el-Fetâvâ'l-İslâmiyye min Dâri'l-İftâi'l-Misriyye XI, Kahire 2010.

Elmalılı, Hamdi (Yazır), "Makâle-i Mühimme”, Beyânülhak, I/18, İstanbul 1324.

Emîr Padişah, Teysîru't-Tahrîr, Kahire 1351.

Fetâvâ-yı Ali Efendi, (haz. Salih el-Kefevî), İstanbul 1311.

Gazzâlî, Ebû Hâmid, el-Mustasfâ fî ilmi’l-usûl, Beyrut 1993.

Hacvî, Muhammed, el-Fikru's-sâmî fî târîhi'l-fikhi'l-İslâmî, Beyrut 1995.

Haddâd (Haddâdî), Ebû Bekir, el-Cevheratün-neyyira, y.y. (Kahire?) 1322 (el-Matbaatü'l-Hayriyye).

Hâdimî, Ebû Saîd, Mecâmiu'l-hakâik, İstanbul 1308.

İbn Abdilber, en-Nemerî, Câmiu beyâni’l-ilm ve fadlih, Kahire 1982.

el- İstizkâr, Kahire 1993. 
el-İntikâ fî fedâili'-selâseti'l-eimmeti'l-fukahâ, Beyrut ts. (Dâru'l-Kütübi'l-İlmiyye).

İbn Âbidîn, Muhammed, Reddü'l-muhtâr, Beyrut ts. (Dâru İhyâi't-Türâsi'l-Arabî).

"Şerhu'l-Manzûmeti'l-müsemmât bi Ukûdi Resmi'l-müftî", Mecmûatürr-Resâil, İstanbul 1320, I, 10-52.

"Neşru'l-arf fî binâi ba’dı'l-ahkâm ale'l-urf”, Mecmûatü'r-Resâil, İstanbul 1320, II, 114147.

İbn Hamdân, Necmeddin, Sıfatüll-fetvâ ve'l-müftî ve'l-müsteftî (nşr. M.N. Elbânî), Dimaşk 1380.

İbn Hazm, Ebû Muhammed, el-Muhallâ, Beyrut 1988.

İbn Hacer el-Askalânî, ed-Dirâye ft tahrîc ehâdisîl-Hidâye (nşr. A. H. Yemânî), Beyrut.

İbn Kayyım el-Cevziyye, I'lâmu'l-muvakkıîn an Rabbi'l-âlemîn, Beyrut 1991.

İbn Kudâme, Abdullah b. Ahmed, el-Muğnî, Beyrut 1984.

İbn Nüceym, Zeynüddin, el-Bahru’r-râik şerhu Kenzid-dekâik, Kahire 1311.

İbn Teymiyye, Takıyyüddin, Mecmûatü’l-fetâvâ, (nşr. A. Cezzar-E.Baz), Mansura 2005

İbnü’s-Salâh, eş-Şehrezûrî, Edebü'l-müftî ve'l-müsteftî (nşr. A. E. Kal'acî), Beyrut 1986.

İzmirli, İsmail Hakkı, İlm-i Hilâf, Dersaadet 1330.

Kâdî İyâz, Ebû'l-Fazl, Tertîbü'l-medârik ve takrîbü'l-mesâlik li ma'rifeti a'lâmi mezhebi Mâlik, (thk. Muhammed T. Tancî ve dğr.), Mağrib 1983.

Kâdîhân, el-Özcendî, el-Fetâvẩl-Hâniyye (el-Fetâvẩl-Hindiyye’nin kenarında), Bulâk 1310.

Kandemir, M. Yaşar, "Muvatta”, DİA, XXXI, 416-418.

Karadâvî, Yûsuf, İslâm Hukuku Evrensellik Süreklilik, (çev. A.Yaman-Y.Işıcık), İstanbul 1997.

Karâfî, Şihabüddin, el-Furûk, Beyrut ts.

el-İhkâm fî̀ temyîzi'l-fetâvâ ani'l-ahkâm ve tasarrufâti'l-kâdî ve'l-imâm (nşr. A. Ebû Ğudde), Beyrut 1995.

Karaman, Hayreddin, İslâm Hukuk Tarihi, İstanbul 1989.

İslâm Hukukunda İctihad, Ankara 1985

Kâsânî, Ebû Bekir, Bedâiu's-sanâi, Beyrut 1986.

Kâsımî, M. Cemaleddin, el-Fetvâ fi'l-İslâm, (thk. M.A. el-Kâdî), Beyrut 1986.

Kaşıkçı, Osman, İslâm ve Osmanlı Hukukunda Mecelle, İstanbul 1997.

Koca, Ferhat, "Mezhep: Fikıh", DİA, XXIX, 537-542.

Mâverdî, Ebû'l-Hasen, Edebü'l-kâdî, (thk. M. H. Serhân), Bağdat 1972.

Mekkî, Muhammed b. Ali, Davâbitu’l-fetvâ, İskenderiye 1418.

Merâğ̂̀, Muhammed Mustafa, el-İctihad fi'l-İslâm, Kahire 1959.

Merğînânî Ali b. Ebî Bekr, el-Hidâye şerhu Bidâyeti’l-mübtedî, İstanbul 1986 
Mübârekî, Ahmed b. Ali, el-Kavlüsş-şâz ve eseruh fi'l-fütyâ, Riyad 1431.

Nakîb, Ahmed b. Muhammed, el-Mezhebü’l-Hanefî, Riyad 2001.

Nevevî, Ebû Zekeriya, Âdabü'l-fetvâ ve’l-müftî ve’l-müsteftî (nşr. B. A. el-Câbî), Dımaşk 1988. el-Mecmû şerhu'l-Mühezzeb (nşr. M. N. el-Mutîî), Cidde ts. (Mektebetü'l-İrşâd). Ravdatu't-tâlibîn (thk. A. A. Abdulmevcûd-A. M. Muavvad), Beyrut 1412/1992.

Okur, Kâşif Hamdi, “İslâm Hukukunda Boşama Yemini (Talâka Yemin) Meselesi”, Hitit Üniversitesi İlahiyat Fakültesi Dergisi, sy. 15 (2009/1), ss. 5-30.

Özşenel, Mehmet, Ebûu Yûsuf'un Hadis Anlayışı, İstanbul 2011.

Senhûrî, Muhammed Ferac, "Mezheplerin Hükümleri Arasında Telfik”, Karaman, Hayreddin, İctihad Taklid ve Telfik Üzerine Dört Risale, İstanbul 1982.

Serahsî, Şemsüleimme (ö. 483/1090), el-Mebsût, İstanbul 1983.

Şerhu’s-Siyeri'l-kebîr, (thk. S. Müneccid - A. Abdülaziz), Kahire 1958-1971.

Seyyid Bey, Mehmed, Usûll-i Fıkıh: Medhal, İstanbul 1333.

Süyûtî, Celaleddin, İhtilâfu’l-mezâhib (nşr. A. Bestevî), Kahire 1989.

Şâfiî, Ebû Abdillah, el-Üm, Beyrut 1993.

Şahin, Osman, İslam Hukukunda Fetvâ Usulü, (doktora tezi 2002), Ondokuz Mayıs Üniversitesi, Samsun.

Şâtıbî, Ebû İshak, el-Muvâfakât, Beyrut 1991.

Şevkânî, Ebû Abdillah, İrşâdü'l-fuhûl (thk. E. el-Eserî), Riyad 2000.

Telkenaroğlu, M. Rahmi, Tevcîhü'l-halef fîmâ’htelefe fîhi's-selef, İzmir 2013.

Tirmizî, Ebû İsa, İlelü't-Tirmizî (el-Câmiu's-sahîh ile birlikte, thk. A.M. Şâkir-M.F. Abdülbakiİ.U.Avd) Kahire 1962.

Yaman, Ahmet, “Fıkhın Sosyolojik Yürürlüğü Bağlamında Fetvâda Değişim”, Diyanet İlmi Dergi, 50/2 (2014), ss. 7-21.

Zehebî, Ebû Abdillah, Menâkıbü'l-İmâm Ebî Hanîfe ve sâhıbeyh, Haydarâbâd ts. (Lecnetü İhyâi'l-Maârifi'n-Nu'mâniyye).

Zerkeşî, Bedreddin, el-Bahru'l-muhît, yy., ts. (Kahire 1992?)

Zeylaî, Cemaleddin, Nasbu'r-râye li tahrîci ehâdîsi'l-Hidâye, Beyrut 1987. 